\title{
Evaluation of Streamflow Traveltime and Streamflow Gains and Losses Along the Lower Purgatoire River, Southeastern Colorado, 1984-92
}

By RUSSELL G. DASH and PATRICK EDELMANN

U.S. GEOLOGICAL SURVEY

Water-Resources Investigations Report 96-4291

Prepared in cooperation with the PURGATOIRE RIVER WATER CONSERVANCY DISTRICT and the ARKANSAS RIVER COMPACT ADMINISTRATION

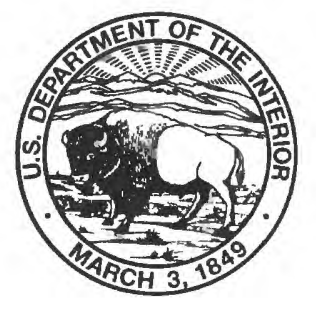




\title{
U.S. DEPARTMENT OF THE INTERIOR \\ BRUCE BABBITT, Secretary
}

\author{
U.S. GEOLOGICAL SURVEY \\ Gordon P. Eaton, Director
}

The use of firm, trade, and brand names in this report is for identification purposes

only and does not constitute endorsement by the U.S. Geological Survey.

For additional information write to:

District Chief

U.S. Geological Survey

Box 25046, Mail Stop 415

Denver Federal Center

Denver, CO 80225-0046
Copies of this report can be purchased from:

U.S. Geological Survey

Branch of Information Services

Box 25286

Denver, CO 80225-0286 


\section{CONTENTS}

Abstract

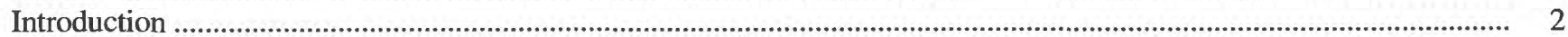

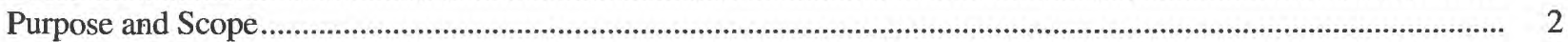

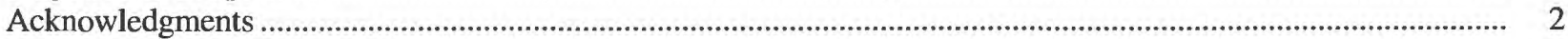

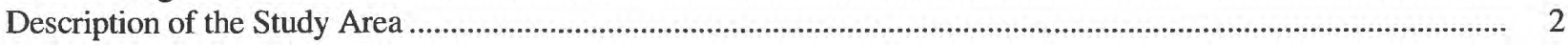

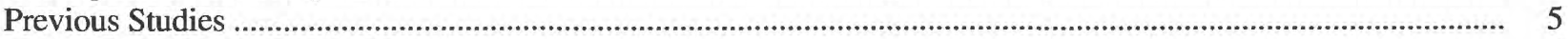

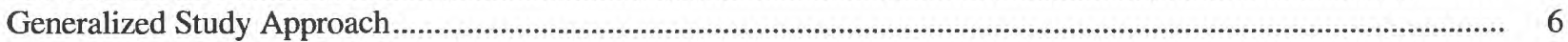

Method of Data Presentation ...................................................................................................................................... 7

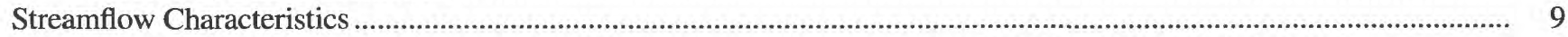

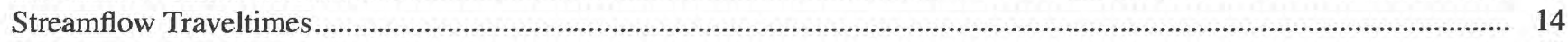

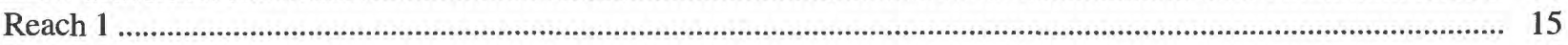

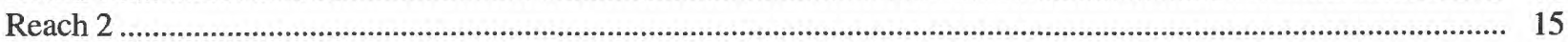

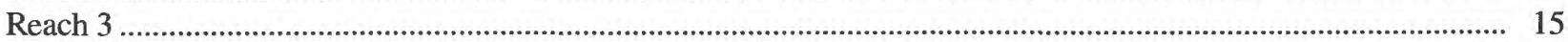

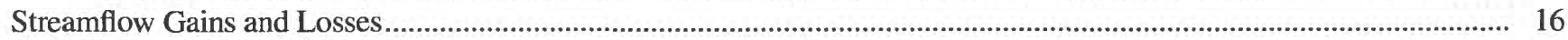

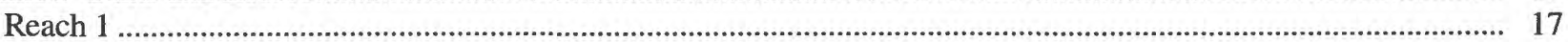

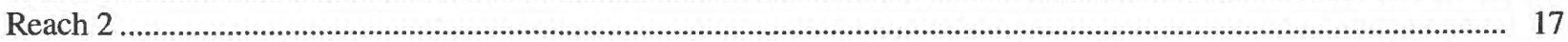

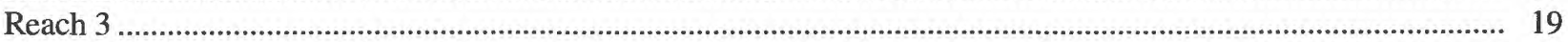

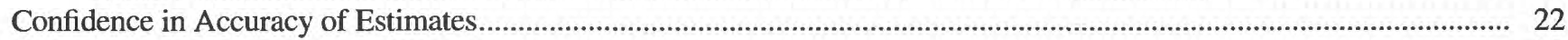

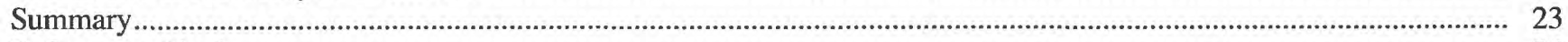

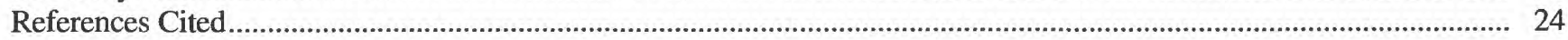

\section{FIGURES}

1. Map showing locations of surface-water sites and river reaches used in the evaluation of streamflow traveltime and streamflow gains and losses in the study area..............................................................................

2. Graph showing mean monthly precipitation and mean monthly air temperature near Hoehne, 1947-92 ................ 5

3. Diagram showing explanation of information for a boxplot ........................................................................

4. Graph showing flow-duration curves for the streamflow-gaging stations, Purgatoire River below Trinidad Reservoir (site Q1) and Purgatoire River at Trinidad (site Q1A) comparing two different periods of streamflow entering the study area, 1957-67 and 1984-92

5. Boxplots showing daily mean streamflow for the streamflow-gaging stations $(A)$ Purgatoire River at Trinidad (site Q1 A), 1957-67; Purgatoire River below Trinidad Reservoir (site Q1), 1984-92; and (B) Purgatoire River near Las Animas (site Q4), 1957-67 and 1984-92.

6. Boxplots showing daily mean streamflow by season for the streamflow-gaging stations Purgatoire River below Trinidad Reservoir (site Q1); Purgatoire River near Thatcher (site Q2); Purgatoire River at Rock Crossing near Timpas (site Q3); and Purgatoire River near Las Animas (site Q4), 1984-92 .

7-9. Graphs showing:

7. Relation of traveltime to instantaneous peak streamflow for two reaches of the study area, 1990-94.

8. Example of $(A)$ unadjusted hydrographs and $(B)$ a traveltime-adjusted upstream hydrograph of daily mean streamflow.

9. Example of selection of streamflow-event periods for analysis of daily streamflow gain and loss ................. 19

10. Boxplots showing daily mean streamflow gains and losses and daily mean streamflow-event gains and losses for reach 2 of the study area, 1984-92

11. Boxplots showing daily mean streamflow gains and losses and daily mean streamflow-event gains and losses for reach 3 of the study area, 1984-92

\section{TABLES}

1. Summary of river reaches, streamflow-gaging stations, river distances, drainage areas, and analysis periods used at selected surface-water sites along the lower Purgatoire River.

2. Percentage of time daily streamflow occurred at selected tributary streams for the upper and middle reaches of the study area, 1957-67 and 1984-92.

3. Statistical summary of daily streamflow estimates of gains and losses and daily streamflow-event gains and losses for the middle and lower reaches of the study area, 1984-92. 
CONVERSION FACTORS AND VERTICAL DATUM

\begin{tabular}{rll}
\hline Multiply & By & To obtain \\
acre & 0.004047 & square kilometer \\
acre-foot (acre-ft) & 1,233 & cubic meter \\
acre-foot per year (acre- $\mathrm{ft} / \mathrm{yr})$ & 1,233 & cubic meter per year \\
cubic foot per second $\left(\mathrm{ft}^{3} / \mathrm{s}\right)$ & 0.02832 & cubic meter per second \\
foot $(\mathrm{ft})$ & 0.3048 & meter \\
inch (in.) & 25.4 & millimeter \\
mile (mi) & 1.609 & kilometer \\
square mile (mi $\left.{ }^{2}\right)$ & 2.59 & square kilometer
\end{tabular}

Degree Fahrenheit $\left({ }^{\circ} \mathrm{F}\right)$ may be converted to degree Celsius $\left({ }^{\circ} \mathrm{C}\right)$ by using the following equation:

$$
{ }^{\circ} \mathrm{C}=5 / 9\left({ }^{\circ} \mathrm{F}-32\right)
$$

Sea level: In this report, "sea level" refers to the National Geodetic Vertical Datum of 1929 (NGVD of 1929)-a geodetic datum derived from a general adjustment of the first-order level nets of both the United States and Canada, formerly called Sea Level Datum of 1929. 


\title{
Evaluation of Streamflow Traveltime and Streamflow Gains and Losses along the Lower Purgatoire River, Southeastern Colorado, 1984-92
}

\author{
By Russell G. Dash and Patrick Edelmann
}

\section{Abstract}

Traveltime and gains and losses within a stream are important basic characteristics of streamflow. The lower Purgatoire River flows more than 160 river miles from Trinidad to the Arkansas River near Las Animas. A better knowledge of streamflow traveltime and streamflow gains and losses along the lower Purgatoire River would enable more informed management decisions about the availability of water supplies for irrigation use in southeastern Colorado. In 1994-95, the U.S. Geological Survey, in cooperation with the Purgatoire River Water Conservancy District and the Arkansas River Compact Administration, evaluated streamflow traveltime and estimated streamflow gains and losses using historical surface-water records.

Traveltime analyses were used along the lower Purgatoire River to determine when streamflows would arrive at selected downstream sites. The substantial effects of diversions for irrigation and unmeasured return flows in the most upstream reach of the river prevented the tracking of streamflow through reach 1 . Therefore, the estimation of streamflow traveltime for the 60.6 miles of river downstream from Trinidad could not be made. Hourly streamflow data from 1990 through 1994 were used to estimate traveltimes of more than 30 streamflow events for about 100 miles of the lower Purgatoire River. In the middle reach of the river, the traveltime of streamflow for the
40.1 miles ranged from about 11 to about 47 hours, and in the lower reach of the river, traveltime for the 58.5 miles ranged from about 6 to about 61 hours. Traveltime in the river reaches generally increased as streamflow decreased, but also varied for a specific streamflow in both reaches.

Streamflow gains and losses were estimated using daily streamflow data at the upstream and downstream sites, available tributary inflow data, and daily diversion data. Differences between surface-water inflows and surface-water outflows in a reach determined the quantity of water gained or lost. In the most upstream reach of the river near Trinidad, difficulties in establishing streamflow traveltimes prevented the estimation of streamflow gains or losses. From 1984 through 1992, more than 2,900 daily estimates of streamflow gains or losses were made for the last 100 miles of the lower Purgatoire River that indicated daily gains and losses in streamflow were common during all four seasons of the year. Although some large daily streamflow gains and losses were computed, most daily estimates indicated small gains and losses in streamflow. The daily median streamflow gain or loss for the middle reach of the river was close to zero during every season, whereas median values for the lower most reach of the river indicated a daily gain in streamflow during every season. 


\section{INTRODUCTION}

The lower Purgatoire River flows more than $160 \mathrm{mi}$ from Trinidad Dam and Reservoir (Bureau of Reclamation, 1964a), hereafter referred to as Trinidad Dam, to its confluence with the Arkansas River near Las Animas, Colorado (fig. 1). Since completion of the dam during the late 1970's, regulation of streamflow has affected the quantity and timing of water available to downstream water users. Water supplies in the valley are overappropriated (Colorado Department of Natural Resources, 1975) and, at times, shortages of irrigation water occur when the demand by canal systems exceeds available streamflow. During water shortages, irrigation canals near the Trinidad area, which have junior water rights, sometimes cannot divert river water because the irrigation canals farther downstream near the Las Animas area, which have senior water rights, have a priority for available streamflow.

Traveltime and gains and losses within a stream are important basic characteristics of streamflow. A better knowledge of streamflow traveltime and streamflow gains and losses along the lower Purgatoire River would enable more informed management decisions about the availability of water supplies for irrigation use in southeastern Colorado. In 1994-95, the U.S. Geological Survey (USGS), in cooperation with the Purgatoire River Water Conservancy District (PRWCD) and the Arkansas River Compact Administration (ARCA), studied these characteristics of streamflow along the lower Purgatoire River.

\section{Purpose and Scope}

This report presents the results of a study that used historical surface-water records to evaluate the characteristics of streamflow traveltime and to estimate streamflow gains and losses along the Purgatoire River downstream from Trinidad Dam, hereafter referred to as the lower Purgatoire River. Streamflow data for 15 surface-water sites and daily streamflow diversion data for 13 irrigation canals were analyzed between sites Q1 and Q4 (fig. 1). Based on available streamflow data collected from January 1984 through December 1992, three river reaches were identified in the lower Purgatoire River for reporting the study analyses. Reach 1 began immediately (0.1 mi) downstream from Trinidad Dam (site Q1) and extended $60.6 \mathrm{mi}$ to Purgatoire River near Thatcher (site Q2). Reach 2 extended $40.1 \mathrm{mi}$ from site Q2 to Purgatoire River at Rock Crossing near Timpas (site Q3). Reach 3 extended $58.5 \mathrm{mi}$ from site Q3 to Purgatoire River near Las Animas (site Q4). In addition, daily mean streamflow and daily streamflow diversion data from January 1957 through December 1967 were used for selected streamflow analyses between sites Q1A and Q1C (fig. 1), and hourly streamflow data from January 1990 through December 1994 were used to estimate the traveltime of selected streamflow peaks between sites Q1 and Q4. For this study, streamflow analyses generally were reported for four seasons. Winter was defined as December through February, spring was March through May, summer was June through August, and fall was September through November.

\section{Acknowledgments}

Personnel from the Colorado Department of Natural Resources, Division of Water Resources, Office of the State Engineer, provided access to written diversion records and electronic data bases. Assistance by R. Dennis Petersen and Steven Kastner in obtaining diversion information for Purgatoire River surface-water sites is gratefully acknowledged. Field tours of irrigated parts of the study area and many helpful discussions were held with personnel from the Office of the State Engineer, Water Division No. 2. Water Commissioner Henry (Danny) Marques, representing Water District 19, and Water Commissioner Donald L. Taylor, and Engineering Technician William (Bill) Howland, representing Water District 17, provided invaluable knowledge of past and present (1995) water operations along the lower Purgatoire River.

\section{Description of the Study Area}

The Purgatoire River originates in the eastern slopes of the Sangre de Cristo Mountains (outside the study area) in south-central Colorado and generally flows northeasterly through parts of three counties [Las Animas, Otero, and Bent (fig. 1)]. 


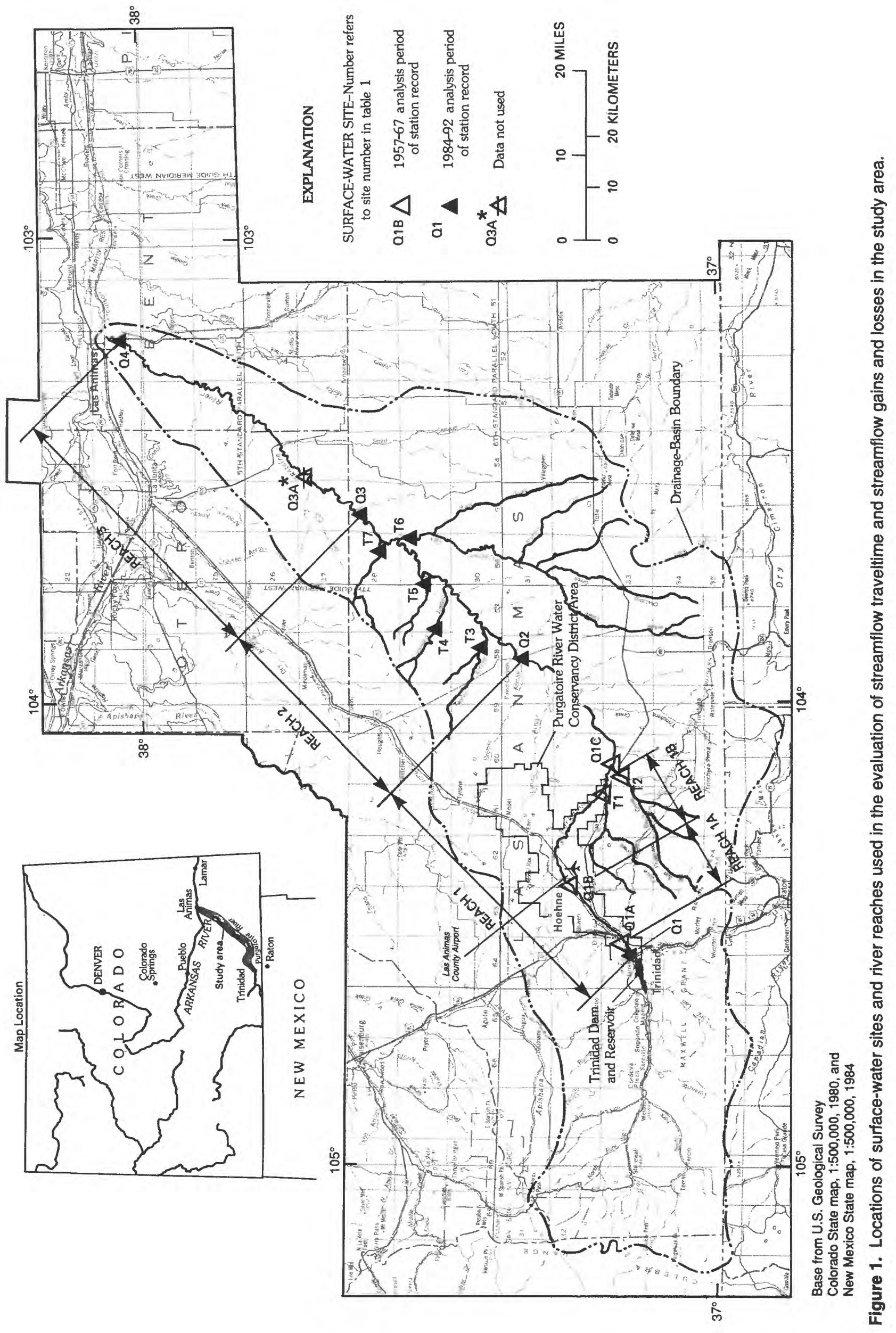


The river has a relatively steep slope in a narrow basin upstream from Trinidad Dam, which is about $1.3 \mathrm{mi}$ upstream from the city of Trinidad. Since the 1970's, the dam has protected the city and the agricultural valley downstream from damaging floods, while water storage in Trinidad Reservoir has provided a more timely water supply for agricultural use on downstream farms and ranches. Before the reservoir was operational, streamflow needed for crop use late in the growing season usually was not available to many users in the study area. The agricultural water supply has historically been erratic (Bureau of Reclamation, 1964a, 1988) with considerable seasonal and annual variations. Maximum water storage in Trinidad Reservoir from 1984 through 1992 ranged from 8,230 to 46,900 acre-ft.

The Purgatoire River traverses porous sandstones, fractured limestones, and impervious shales overlain in most areas of the valley by shallow (generally less than $50 \mathrm{ft}$ thick), unconsolidated alluvial deposits that range from a few hundred feet to more than $1 \mathrm{mi}$ in width. A general absence of large-capacity irrigation wells in the study area indicates that these alluvial deposits might not be suitable for ground-water development. The river channel generally varies in width from about 10 to $400 \mathrm{ft}$ and contains a mixture of riverine deposits mostly consisting of gravels and sands. The alluvial deposits near the river might be in hydraulic connection with the river. However, sufficient geohydrologic information to define the relation of ground water to surface water is not available. A more complete description of the geology along the lower Purgatoire River is presented by Qazi and Krason (1976).

The study area has a semiarid continental climate typical of the Great Plains province. Mean monthly precipitation and mean air temperature at Las Animas County Airport near Hoehne (fig. 1) for 1947-92 are shown in figure 2. Mean annual precipitation on the eastern plains of southeastern Colorado averages about 13 in. (fig. 2), most of which falls during spring and summer thunderstorms that have varying amounts of precipitation from storm to storm and from site to site. Mean monthly air temperature increases steadily to a maximum in July then decreases steadily to a minimum in January (fig. 2). Throughout the study area, potential evapotranspiration greatly exceeds precipitation. Natural vegetation present on the semiarid prairie throughout the area primarily is low grasses and shrubs, with scattered stands of pinon and juniper trees on some of the higher elevation hills. Along the flood plain of the lower Purgatoire River, there are mature stands of salt cedars and other types of woody phreatophytes (Lindauer and Ward, 1968). The average growing season for pasture grasses, alfalfa, and other types of hay crops (Colorado Cooperative Crop and Livestock Reporting Service, 1995) irrigated in the study area is about 8 months (U.S. Department of Agriculture, 1988).

Most irrigated land along the lower Purgatoire River extends 35 river miles in the valley downstream from Trinidad and along gently sloping plateaus northeast of Trinidad. About $25 \mathrm{mi}$ farther downstream from this irrigated area, the river flows through the steep-walled (as much as $500 \mathrm{ft}$ ) Purgatoire River Canyon, a narrow 40-mi-long reach flanked on either side of the river by semiarid prairie. After leaving the canyon, the river flows about $60 \mathrm{mi}$ through a relatively flat and wide valley with two tracts of irrigated land before its confluence with the Arkansas River near Las Animas. A detailed description of surface-water distribution in southeastern Colorado is provided by Abbott (1985); the report describes water operations after 1977 and provides site information about surface-water-withdrawal locations along the lower Purgatoire River between Trinidad and Las Animas.

Thirteen irrigation canals in the study area divert streamflow from the Purgatoire River usually from April through the middle of November; peak diversions generally are largest from June through August. At times, there is little surface-water flow in some river reaches because the irrigation canals divert the entire flow of the river. Canals withdrawing streamflow are Antonio Lopez, Baca Joint, Chilili, Enlarged Southside, El Moro, Model, Johns Flood, Hoehne, Burns-Duncan, Lewelling-McCormick, Salas, Ninemile, and Highland. Parshall flumes that vary from small structures $\left(6-\mathrm{ft}^{3} / \mathrm{s}\right.$ capacity) to moderately large structures $\left(700-\mathrm{ft}^{3} / \mathrm{s}\right.$ capacity) are used to measure streamflow into the irrigation canals. Each canal has a maintained recording device located near the river that records daily streamflow diversions (Henry Marques, Colorado Department of Natural Resources, oral commun., 1995). About 19,700 acres of cropland in the vicinity of Trinidad are irrigated through 11 canals, which are part of the PRWCD (Bureau of Reclamation, 1964a). 


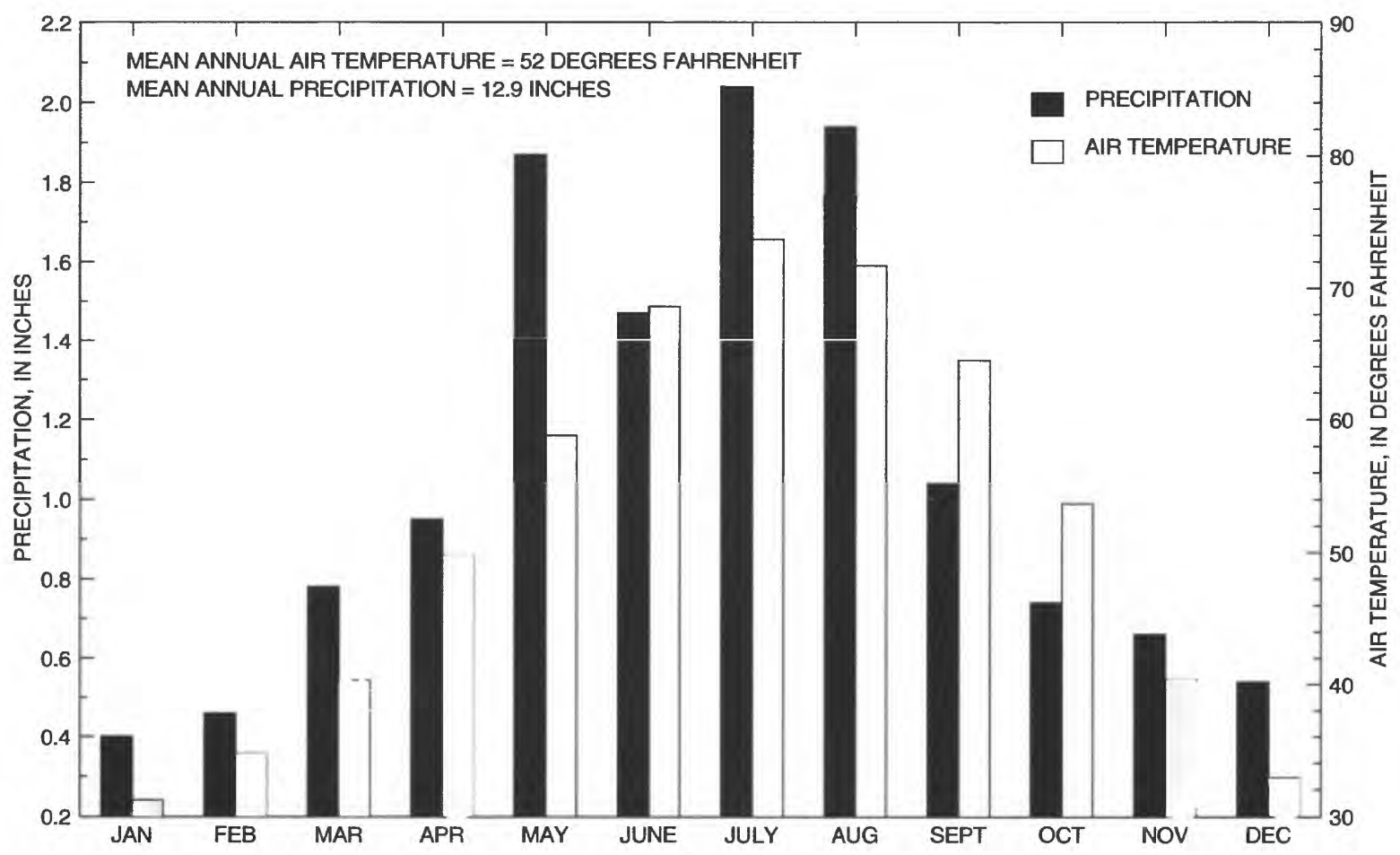

Figure 2. Mean monthly precipitation and mean monthly air temperature near Hoehne, 1947-92.

There are no diversions between the last PRWCD lands (downstream from site Q1C) and the Ninemile Canal [upstream from site Q3A (fig. 1)]. Downstream from Ninemile Canal, streamflow is diverted by two canals to about 4,500 acres of cropland (Duane Helton, Tipton and Kalmbach, Inc., written commun., 1984). Diversion records indicate that average diversion in the study area was about 73,200 acre-ft/yr during 1957-67 and about 71,800 acre-ft/yr during 1984-92 (R.D. Petersen, Colorado Department of Natural Resources, written commun., 1994).

\section{Previous Studies}

No comprehensive studies of water resources for the entire lower Purgatoire River have been completed. Many of the previous studies that have been completed in the study area addressed local problems and were made prior to the commencement of operation of Trinidad Reservoir in the late 1970's. The review of these earlier studies indicated that published and unpublished reports relating to previous surface-water investigations in the study area generally were limited to a specific hydrologic condition that occurred in a particular locality along the river.

Some of the earliest studies of streamflow were done in the 1920's (Colorado Department of Natural Resources, written commun., 1925) and indicated a sharp decrease in streamflow between Trinidad (site Q1A) and Hoehne [site Q1B (fig. 1)], which was attributed to irrigation diversions upstream from Hoehne. Farther downstream, an increase in streamflow was observed between Hoehne and Alfalfa [site Q1C (fig. 1)] and generally was attributed to irrigation return flows. These studies also reported a decrease in streamflow between Alfalfa and the Highland Canal (about $110 \mathrm{mi}$ downstream from Alfalfa) during periods of reasonably steady water stage using occasional field measurements of streamflow along the river. However, the studies apparently did not always include a detailed accounting of tributary streamflow and irrigation activities that occurred along the river. These studies resulted in court decree no. 1325 [Bent County District Court (September 8, 1925)] 
establishing in-channel streamflow losses between the Ninemile Canal [site Q3A (fig. 1)] and the Highland Canal, a distance of about 32 river miles, that varied from streamflow losses of $3 \mathrm{ft}^{3} / \mathrm{s}$ in winter to $8 \mathrm{ft}^{3} / \mathrm{s}$ during summer.

A study by the Bureau of Reclamation (1964b) reported that "it is generally recognized that natural channel losses of the Purgatoire River are considerable" (p. 71) in certain reaches, and "the normal flow of the Purgatoire River at Trinidad has very little chance of reaching Alfalfa" (p. 72). The study also reported that "fairly reliable loss rates can be determined for 105 river miles" (p. 79) on water transported between Alfalfa and the Highland Canal. Channel losses were not estimated for river reaches upstream from Alfalfa or downstream from the Highland Canal because of the difficulty in estimating diversions and return flows in these irrigated reaches of the lower Purgatoire River. Generally, there were few records of tributary inflow available for the analysis periods used in this study.

A more recent study (Colorado Department of Natural Resources, 1975) attempted to determine the amount of streamflow needed for downstream deliveries to satisfy the senior water rights of the Highland Irrigation Company, operator of the last irrigation canal diverting from the lower Purgatoire River. The study was conducted during summer, and the riverbed was generally dry. Streamflow in the Purgatoire River was regulated for several days using bypasses at the Enlarged Southside Ditch, a large canal near Trinidad that can divert a large percentage of the available streamflow. Streamflow measurements were made to determine conveyance losses from Alfalfa to the Highland Canal. Following several incremental increases to streamflow near Trinidad, streamflow finally arrived at the Highland Canal more than 16 days after the upstream releases started. During this study, streamflow losses of 20 percent to more than 80 percent were indicated in some river reaches (Colorado Department of Natural Resources, 1975).

Another analysis of data from the study described in the previous paragraph indicated that a traveltime of approximately 5 days for water to flow about $110 \mathrm{mi}$ from Alfalfa to the Highland Canal was more reasonable than the 16 days reported in the study by the State (David E. Fleming, David E. Fleming
Company, written commun., 1975). Fleming concluded that the $35 \mathrm{ft}^{3} / \mathrm{s}$ being supplied downstream from Alfalfa in the first 10 days of the conveyance test was insufficient to result in measurable streamflow at the Highland Canal. Streamflow losses of about $37 \mathrm{ft}^{3} / \mathrm{s}$ were reported by Fleming along the $110 \mathrm{mi}$ of river between Alfalfa and the Highland Canal.

Qazi and Krason (1976) reviewed and analyzed many of the previous studies in the basin and concluded that insufficient data were available to quantify streamflow losses along the lower Purgatoire River. Qazi and Krason (1976) concluded that (1) the irrigation season generally was a period of streamflow loss and the nonirrigation season generally was a period of streamflow gain in the river reaches from Trinidad (site Q1A) to Hoehne (site Q1B) and from Alfalfa (site Q1C) to the Ninemile Canal (site Q3A); and (2) streamflow was observed to generally increase in the river reaches from Hoehne to Alfalfa and from the Ninemile Canal to the Las Animas streamflow-gaging station (site Q4).

\section{Generalized Study Approach}

A compilation of historical streamflow records collected by Federal and State agencies along the lower Purgatoire River was made for the purposes of selecting data and time periods that could be used to estimate streamflow traveltime and streamflow gains and losses. Streamflow traveltime is the amount of time it takes for a parcel of water to travel some known river distance downstream. Streamflow gains and losses are the amount of water that is interchanged between surface- and ground-water systems along the river and are computed by subtracting all the surface water leaving a river reach from all the surface water entering a river reach. The review of available streamflow records indicated (1) mainstem streamflow data along the lower Purgatoire River were available since 1895; (2) tributary streamflow data in the study area were limited and available for only a few tributaries; (3) the best continuity of tributary streamflow data was for 1957-67 and 1984-92; (4) daily mean streamflow and daily diversion data were available for both of these time periods; and (5) hourly streamflow data needed to evaluate streamflow traveltimes were readily available after 1990. 
Streamflow traveltimes were estimated for river reaches using hourly streamflow data collected from 1990 to 1994 at four mainstem gaging stations [sites Q1, Q2, Q3, and Q4 (fig. 1)]. The estimates of reach traveltime were derived by compiling the time, in hours, for distinguishable streamflow peaks at the upstream site to arrive at the downstream site (peak-to-peak traveltime). Ungaged inflows were minimal during the intervals used for analysis.

Streamflow gains and losses were evaluated using daily streamflow data at the upstream and downstream sites, available tributary data, and daily diversion data. Because gain-and-loss studies attempt to account for all inflows and outflows in a river reach, the time periods that contained some tributary data were used to characterize streamflow gains and losses. However, the amount of tributary data available to quantify surface-water inflows were limited and varied temporally and spatially in each reach. The two time periods that contained the most tributary data were 1957-67 and 1984-92. Streamflow data were available during these two periods at eight mainstem stations and seven tributary stations (table 1). Data from the mainstem station Purgatoire River at Ninemile Dam near Higbee [site Q3A (table 1)] were not used because of unresolved concerns about the quality of the station records (both time and stage) during some streamflow periods. The 1984-92 period was selected for most of the gain-and-loss analyses because this period had the best continuity of streamflow data for the entire lower Purgatoire River, and this period represented the streamflow conditions that have existed along the lower Purgatoire River since 1979 when water regulation commenced at Trinidad Reservoir (Bureau of Reclamation, 1988). During 1984-92, there were few streamflow data available for the tributary streams and other side-channel inflows in reach 1 . In reach 2 , streamflow data for five gaged tributaries [sites T3-T7 (table 1)] were used in the analysis, but data were not available for several other small ephemeral tributaries in reach 2 . In reach 3 , no streamflow data were available during any time period for the tributary streams and other side-channel inflows. Site Q4, which is located about $3.3 \mathrm{mi}$ upstream from the mouth of the Purgatoire River, was periodically affected to some extent by surface-water return flows from the Las Animas Consolidated and Las Animas Consolidated Extension Canals that receive water from outside the study area (Abbott, 1985). All surface-water outflows (diversions for irrigation) in the river reaches were measured and accounted for in the computation of daily streamflow gains and losses.

Because the analysis of 1984-92 data for reach 1 did not result in quantification of streamflow gains and losses and because there were tributary data available for 1957-67, an analysis of gains and losses for a part of reach 1 was made from January 1957 through December 1967. Based on available data during this period, $34.2 \mathrm{mi}$ of the Purgatoire River located between mainstem sites Q1A and Q1C was divided into two subreaches. The first subreach, reach $1 \mathrm{~A}$ (fig. 1), extended $10.8 \mathrm{mi}$ from the Purgatoire River at Trinidad (site Q1A) to the Purgatoire River near Hoehne (site Q1B). Streamflow data for sites Q1A and Q1B (table 1) and diversion data for seven irrigation canals in reach $1 \mathrm{~A}$ were used in evaluating streamflow gains and losses. Most of the diverted water in reach $1 \mathrm{~A}$ was conveyed in unlined canals to cropland areas located farther downstream. There were several small ephemeral tributaries that might have contributed additional inflows to reach $1 \mathrm{~A}$ in response to rainfall. The second subreach, reach $1 B$ (fig. 1), extended $23.4 \mathrm{mi}$ from site Q1B to the Purgatoire River near Alfalfa (site Q1C). Streamflow data for sites Q1B and Q1C (table 1), for two gaged tributaries [sites T1 and T2 (table 1)], and diversion data for four irrigation canals in reach 1B were used in evaluating streamflow gains and losses. No streamflow data were available for other ephemeral tributaries that might have contributed additional inflows to reach $1 \mathrm{~B}$.

Because numerous tributary streams were ungaged along the lower Purgatoire River and because large errors can occur for a river reach in quantifying gains and losses when unmeasured inflows or outflows exist, the available tributary streamflow data for reaches 1 and 2 were used to evaluate whether ungaged tributary inflow affected estimates of streamflow gains and losses.

\section{Method of Data Presentation}

Streamflow data and results of the analyses of streamflow gains and losses are illustrated in this report using boxplots. A boxplot (fig. 3) 
Table 1. Summary of river reaches, streamflow-gaging stations, river distances, drainage areas, and analysis periods used at selected surface-water sites along the lower Purgatoire River

[NN, no numbers; --, no data; ND, no data were used]

\begin{tabular}{|c|c|c|c|c|c|}
\hline $\begin{array}{l}\text { Site } \\
\text { number } \\
\text { (see } \\
\text { fig. 1) }\end{array}$ & $\begin{array}{l}\text { U.S. Geological } \\
\text { Survey } \\
\text { station } \\
\text { number }\end{array}$ & $\begin{array}{l}\text { Station } \\
\text { name }^{1}\end{array}$ & $\begin{array}{c}\text { Distance } \\
\text { downstream } \\
\text { from } \\
\text { Trinidad Dam } \\
\text { (river miles) }\end{array}$ & $\begin{array}{c}\text { Drainage } \\
\text { area } \\
\text { (square miles) }\end{array}$ & $\begin{array}{l}\text { Analysis } \\
\text { period of } \\
\text { station } \\
\text { record } \\
\text { (years) }\end{array}$ \\
\hline \multicolumn{6}{|c|}{ Reach 1} \\
\hline NN & NN & Trinidad Dam (upstream study boundary) & 0 & -- & -- \\
\hline Q1 & 07124410 & Purgatoire River below Trinidad Reservoir & 0.1 & 672 & 1984-92 \\
\hline Q1A & 07124500 & Purgatoire River at Trinidad & 1.3 & 795 & $1957-67$ \\
\hline Q1B & 07125000 & Purgatoire River near Hoehne & 12.1 & 857 & $1957-67$ \\
\hline $\mathrm{T} 1$ & 07125100 & Frijole Creek near Alfalfa & -- & 80 & $1957-67$ \\
\hline $\mathrm{T} 2$ & 07125500 & San Francisco Creek near Alfalfa & - & 160 & $1957-67$ \\
\hline Q1C & 07126000 & Purgatoire River near Alfalfa & 35.5 & 1,306 & $1957-67$ \\
\hline \multicolumn{6}{|c|}{ Reach 2} \\
\hline Q2 & 07126300 & Purgatoire River near Thatcher & 60.6 & 1,791 & 1984-92 \\
\hline T3 & 07126325 & Taylor Arroyo below Rock Crossing near Thatcher & -- & 48.4 & 1984-92 \\
\hline T4 & 07126390 & Lockwood Canyon Creek near Thatcher & -- & 41.4 & 1984-92 \\
\hline T5 & 07126415 & Red Rock Canyon Creek at mouth, near Thatcher & -- & 48.8 & 1984-92 \\
\hline T6 & 07126470 & Chacuaco Creek at mouth, near Timpas & - & 424 & 1984-92 \\
\hline T7 & 07126480 & Bent Canyon Creek at mouth, near Timpas & - & 56.2 & $1984-92$ \\
\hline \multicolumn{6}{|c|}{ Reach 3} \\
\hline Q3 & 07126485 & Purgatoire River at Rock Crossing near Timpas & 100.7 & 2,635 & 1984-92 \\
\hline Q3A & 07126500 & Purgatoire River at Ninemile Dam near Higbee & 113.5 & 2,752 & ND \\
\hline Q4 & 07128500 & $\begin{array}{l}\text { Purgatoire River near Las Animas } \\
\text { (downstream study boundary) }\end{array}$ & 159.2 & 3,318 & 1984-92 \\
\hline $\mathrm{NN}$ & NN & Purgatoire River at mouth & 162.5 & -- & - \\
\hline
\end{tabular}

${ }^{1}$ Station names may be different from the stream names shown in figure 1.

${ }^{2}$ Length of available streamflow record used for daily traveltime and gain-and-loss analyses; streamflow records may exist for other time periods.

is a useful visual tool for examining the central tendency and for summarizing the distribution of selected streamflow data. When plotted on the same scale, boxplots can be compared visually, and differences and similarities among surface-water sites or between different seasons can be identified. The median (50th percentile) is the center value of the data distribution and is shown as a solid line splitting the box, which indicates that 50 percent of the data are less than or equal to that reported value. The quartile skew of the data distribution is seen by comparing the parts of the box above and below the median line. For a linear scale, if the upper part is larger than the lower part, the data are skewed to the high values. The interquartile range represents the middle 50 percent of the data (variation or spread of the data) and is the enclosed part of the box between the 25th and 75th percentiles. The lengths of the vertical lines (whiskers) compared to the length of the box indicate how stretched the tails of the data distribution are. The whiskers extend to the last observation that is within 1.5 times the length of the box (1.5 times the interquartile range). Standard boxplots (Helsel and Hirsch, 1992) provide concise visual summaries of the presence or absence of unusual data values (outliers) from the rest of the boxplot. Extreme observations between 1.5 and 3 times the interquartile range are plotted individually with an asterisk (outside values). Observations greater than 3 times the interquartile range are distinguished by plotting them with a small circle (far-out values). The width of the box has no particular meaning in boxplots. Further information on boxplots is contained in Helsel and Hirsch (1992). 


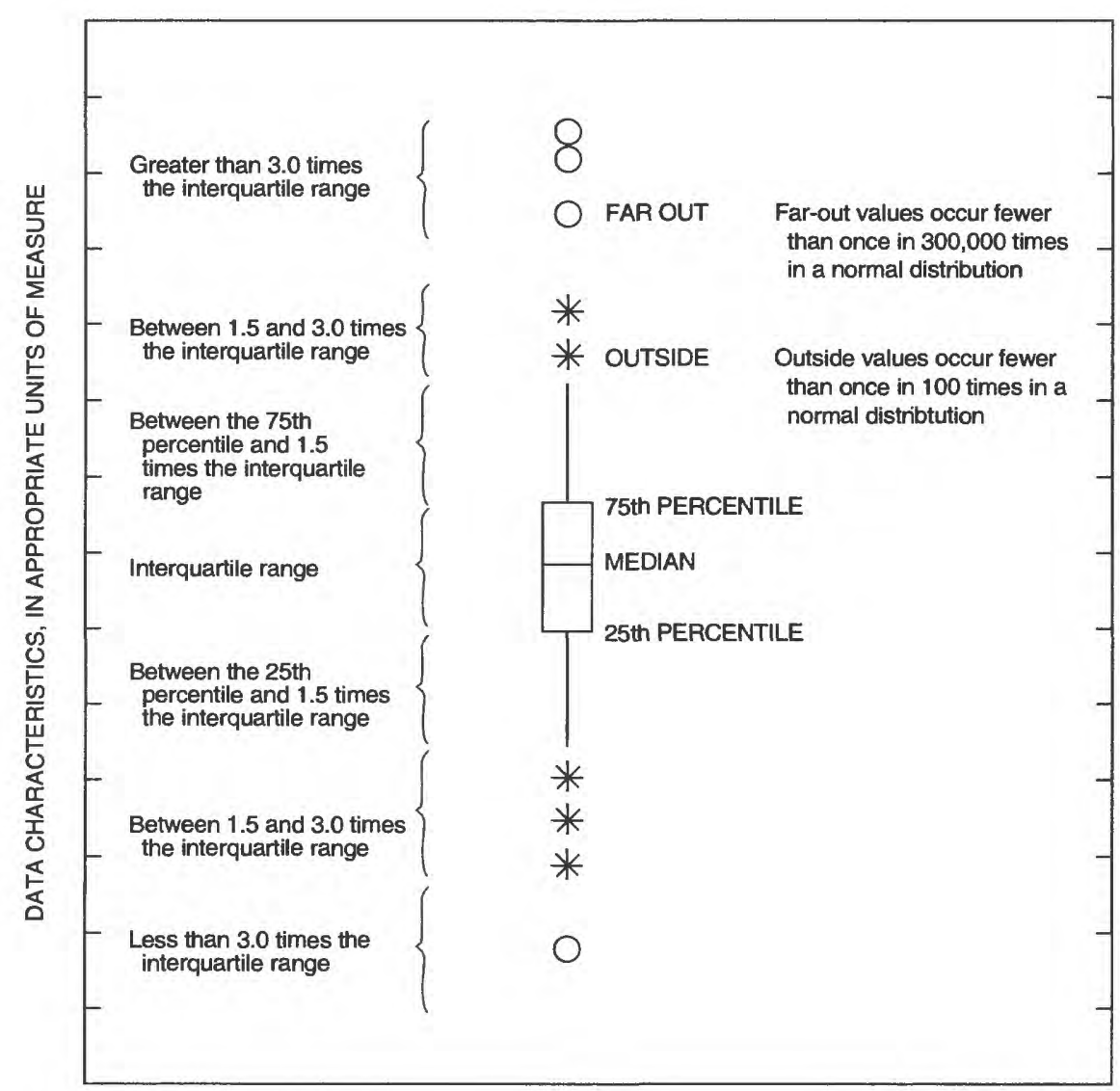

Figure 3. Explanation of information for a boxplot.

\section{STREAMFLOW CHARACTERISTICS}

Knowledge of streamflow characteristics is essential when attempting to evaluate traveltime and gains and losses because streamflow (discharge) data describe the volume of water moving per unit-time in a river system. In the lower Purgatoire River, waterstage data generally were collected at 15 -minute intervals, from which surface-water records (daily mean discharge) were computed by standard methods and procedures described by Rantz and others (1982). Most of the available streamflow records were rated good, with an uncertainty error of less than \pm 10 percent, except during winter when ice effects frequently were recorded at the streamflow-gaging stations in the study area.

A flow-duration curve, which is a cumulative frequency curve that indicates the percent of time a specified streamflow was equaled or exceeded, is particularly suitable for evaluating the historical record of streamflow for two different periods of time.
Flow-duration analysis of daily mean streamflow was done for two stations: Purgatoire River at Trinidad (site Q1A) and Purgatoire River below Trinidad Reservoir (site Q1). These two mainstem stations were selected to represent conditions of streamflow entering the study area during two relatively long-term periods of time before and after Trinidad Dam became operational in 1979. The flow-duration curve for site Q1A was computed for 11 continuous years (1957-67) of streamflow data, whereas the flowduration curve for site $\mathrm{Q} 1$ was computed for 9 continuous years (1984-92) of streamflow data; these two periods were used for most of the study analyses of streamflow gains and losses.

Comparison of the flow-duration curves from site Q1A and site Q1 (fig. 4) indicates that (1) daily mean streamflow entering the study area was different between these two periods; (2) large streamflows (greater than $280 \mathrm{ft}^{3} / \mathrm{s}$ ) were more common during 1957-67 at site Q1A; (3) base flow (less than $40 \mathrm{ft}^{3} / \mathrm{s}$ ) 
was large during 1957-67; and (4) streamflows from 40 to $280 \mathrm{ft}^{3} / \mathrm{s}$ occurred more frequently during 1984-92 at site Q1 than during 1957-67 at site Q1A, probably as a result of the controlled releases from storage at Trinidad Reservoir.

Seasonal streamflow entering the study area between 1957-67 and 1984-92 is shown in figure 5. The daily streamflow measured at site Q1A between 1957-67 represents a period of unregulated streamflows (excluding upstream diversions) that existed in the study area before operation of Trinidad Dam. The daily streamflow measured at site Q1 during 1984-92 represents a period when streamflow was regulated by the operation of Trinidad Dam and when demands of PRWCD canal systems near Trinidad and other canal systems in the study area needed to be met. A comparison of streamflow at sites Q1 and Q1A (fig. $5 \mathrm{~A}$ ) indicates that regulation of the Purgatoire River at Trinidad Dam has affected the seasonal quantity and timing of streamflow into the study area. Daily median streamflow during 1984-92 (site Q1) was larger than during 1957-67 (site Q1A) during the summer, but generally was smaller during the other three seasons (fig. 5A).

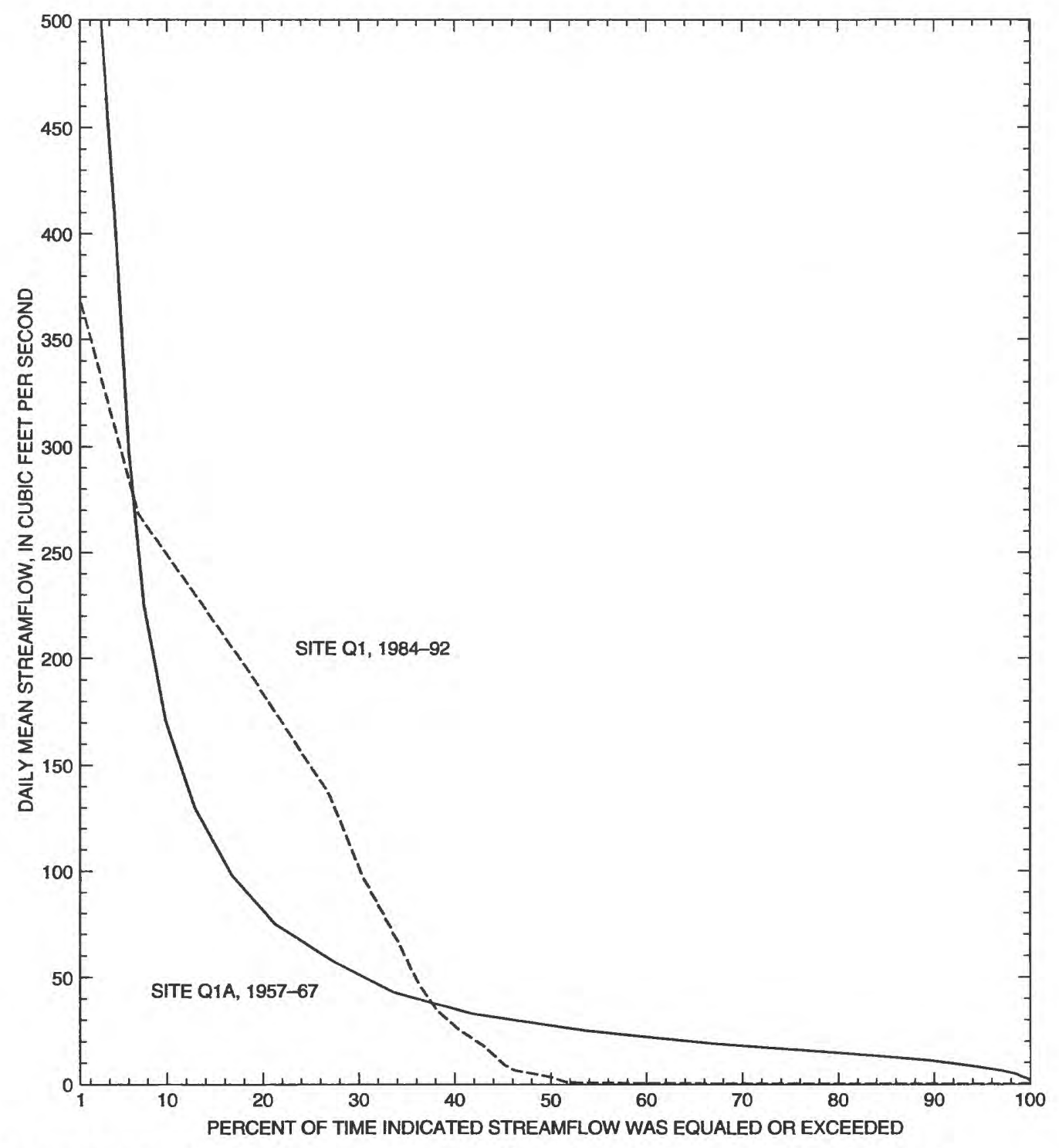

Figure 4. Flow-duration curves for the streamflow-gaging stations, Purgatoire River below Trinidad Reservoir (site Q1) and Purgatoire River at Trinidad (site Q1A) comparing two different periods of streamflow entering the study area, 1957-67 and 1984-92. 


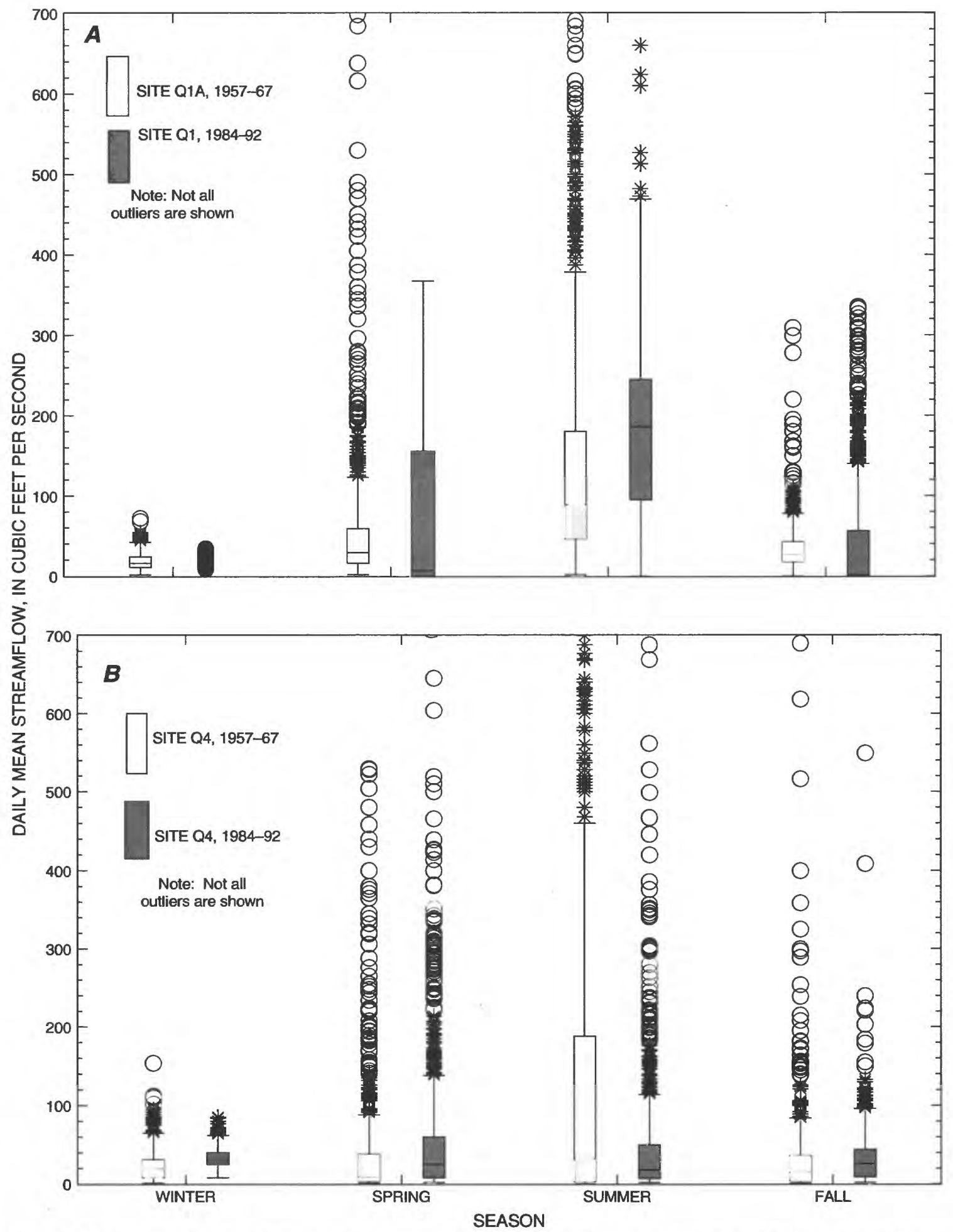

Figure 5. Boxplots showing daily mean streamflow for the streamflow-gaging stations (A) Purgatoire River at Trinidad (site Q1A), 1957-67; Purgatoire River below Trinidad Reservoir (site Q1), 1984-92; and (B) Purgatoire River near Las Animas (site Q4), 1957-67 and 1984-92. 
During the winters of 1957-67, daily mean streamflow at site Q1A generally was small (median of $16 \mathrm{ft}^{3} / \mathrm{s}$ ), then streamflow increased in the spring, with more days of large streamflow occurring as a result of snowmelt runoff upstream from Trinidad. The daily median $\left(89 \mathrm{ft}^{3} / \mathrm{s}\right)$ and range in streamflow increased in the summer as snowmelt and rainfall runoff resulted in more days of large streamflows. The daily median $\left(27 \mathrm{ft}^{3} / \mathrm{s}\right)$ and range in streamflow diminished sharply in the fall although rainfall runoff events resulted in some days of large streamflow (fig. 5A).

During the winters of 1984-92, daily mean streamflow at site Q1 generally was zero, although there were times when small releases occurred from Trinidad Reservoir for livestock watering. Reservoir releases generally were small (median of $6.5 \mathrm{ft}^{3} / \mathrm{s}$ ) during the spring (fig. $5 \mathrm{~A}$ ), whereas during the summer, relatively large streamflows were sustained as water was released from the reservoir to meet the irrigation demand of crops in the study area. During summer, streamflow generally was greater than $186 \mathrm{ft}^{3} / \mathrm{s}$. Reservoir releases were substantially decreased during fall, resulting in a daily median streamflow of about $1 \mathrm{ft}^{3} / \mathrm{s}$.

Comparison of daily mean streamflow leaving the study area during 1957-67 to streamflow leaving during 1984-92 at site Q4 (fig. 1), a downstream distance of $159.2 \mathrm{mi}$, indicated that seasonal streamflow characteristics at this last river station generally were similar for the two periods (fig. $5 B$ ). Seasonal streamflow at site Q4 was affected by return flows resulting from irrigation activities farther upstream. During 1984-92, daily median streamflow at site Q4 in winter and spring was larger than during 1957-67 (fig. 5B). During summer, the range and daily median streamflow were larger during 1957-67 because snowmelt and rainstorms from the upper basin resulted in more unregulated streamflow entering the lower basin. During 1984-92, Trinidad Reservoir stored many large daily runoff events, resulting in substantially fewer days of large streamflow being released downstream. Daily median streamflow diminished some in the fall during 1957-67, although the range of daily streamflows was similar to 1984-92.
Downstream daily variations in streamflow at Purgatoire River below Trinidad Reservoir (site Q1), Purgatoire River near Thatcher (site Q2), Purgatoire River at Rock Crossing near Timpas (site Q3), and Purgatoire River near Las Animas (site Q4) from January 1984 through December 1992 are summarized by season in figure 6 . Daily streamflow recorded during 1984-92 at these four sites indicated that variations in streamflow of the Purgatoire River downstream from site Q2 were fairly similar during 1984-92. Streamflow recorded at sites Q2 and Q4 were affected by water operations and return flows from the irrigated areas upstream from these two sites. Streamflow at site Q4 also was periodically affected to some extent by return flows from outside the study area, as discussed in the "Generalized Study Approach" section. Daily median streamflow during winter at sites Q2, Q3, and Q4 (fig. 6) was substantially larger than that at site Q1; a likely source for the increased streamflow was ground-water discharge to the river reach, derived in part, from irrigation return flows. Daily median streamflow during winter at sites Q2, Q3, and Q4 was about the same range, indicating there was little additional ground-water discharge to the river in reaches 2 and 3 (tributary streamflow was minimal during winter).

Tributaries in the study area generally drain relatively shallow uplands on both sides of the valley. Most of the tributaries are ephemeral streams that flow in response to snowmelt or high-intensity precipitation. A recent study for an area adjacent to the Purgatoire River Canyon (von Guerard and others, 1993) reported that most tributary streamflow was intermittent, of short duration, and resulted from rainfall runoff during May through October. Tributary streamflow that results from intense precipitation during spring, summer, and early fall generally is characterized by a rapid rise in peak streamflow. Tributary runoff in reach 2 contributed a relatively small inflow volume to the annual streamflow of the Purgatoire River (von Guerard and others, 1987). Between 1984 and 1992, total tributary streamflow measured at five gaged tributaries between sites Q2 and Q3 contributed from 0.8 to 10.4 percent of the annual streamflow measured at Purgatoire River at Rock Crossing near Timpas (site Q3, fig. 1). 

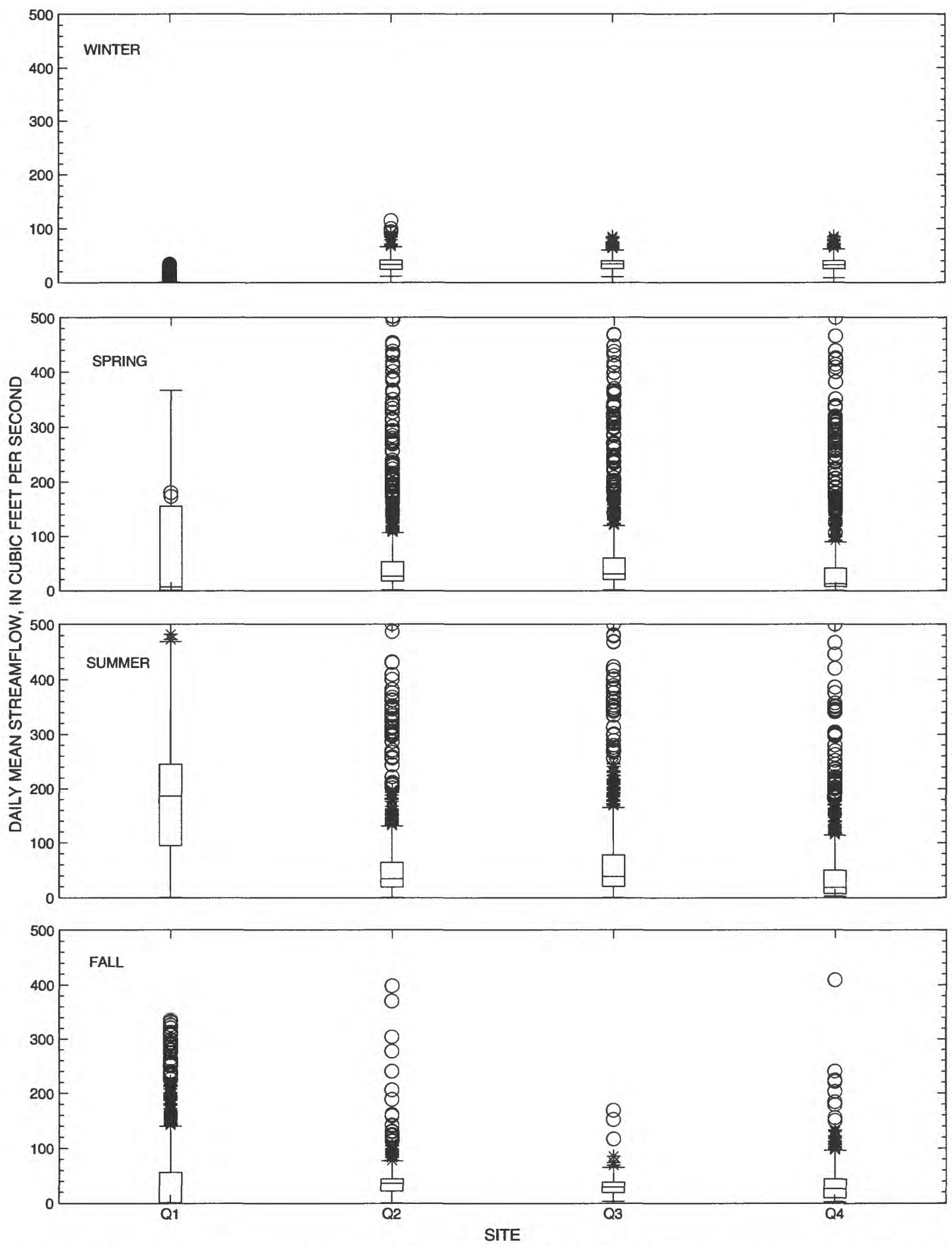

Figure 6. Boxplots showing daily mean streamflow by season for the streamflow-gaging stations Purgatoire River below Trinidad Reservoir (site Q1); Purgatoire River near Thatcher (site Q2); Purgatoire River at Rock Crossing near Timpas (site Q3); and Purgatoire River near Las Animas (site Q4), 1984-92. (Not all outliers are shown, especially for spring and summer.) 
The availability and completeness of streamflow data for tributary streams in the area varied seasonally and spatially by river reach. Analysis of daily mean streamflow data at two gaged tributaries in reach 1 [sites T1 and T2 (fig. 1)] from 1957-67 indicated that tributaries had streamflow a large percentage of the time, but tributary streamflow generally contributed less than 10 percent of the mainstem streamflow (table 2). Analysis of daily mean streamflow data at five gaged tributaries in reach 2 [sites T3-T7 (fig. 1)] from 1984-92 indicated that tributaries had streamflow between 38 and 58 percent of the time, but contributions that exceeded 10 percent of mainstem flow occurred infrequently (table 2). A large percentage of the time, gaged tributary inflow in reaches 1 and 2 contributed less than 10 percent of the mainstem streamflow (table 2), indicating that these seven gaged tributaries generally were not a source of substantial streamflow (inflow) to the lower Purgatoire River.

Daily precipitation measured between 1984 and 1992 at National Weather Service stations in various parts of the study area were checked for correlations with tributary streamflow measured in reach 2 ; the relation would have been used to adjust daily streamflow contributions for the ungaged tributaries in reaches 1 and 3 . The correlation analysis indicated that there were temporal and spatial differences in daily precipitation among the collection sites in the study area. Because of this variability affecting the data, daily precipitation was not correlated closely enough to estimate ungaged tributary streamflows or to determine, with reasonable accuracy, on which days rainfall runoff occurred in a river reach.

\section{STREAMFLOW TRAVELTIMES}

Traveltime information is valuable in waterresources management to determine when a reservoir release or flood wave would arrive at a downstream location. In this study, traveltime information was needed for time adjustments to the streamflow at the upstream site in a reach; these time adjustments were used to improve the accuracy of estimates of streamflow gain and loss. Hourly streamflow data collected from 1990 to 1994 were used to evaluate the relation of traveltime to streamflow at four river stations [sites Q1, Q2, Q3, and Q4 (fig. 1)]. The estimates of reach traveltime were derived by determining the time, in hours, for distinguishable streamflow peaks at the upstream site to arrive at the downstream site (peak-to-peak traveltime). Suitable streamflow hydrographs used in assessing traveltimes in a reach consisted of periods of reasonably steady antecedent streamflow, followed by a distinguishable increase and decrease in streamflow. Hydrograph periods were selected so that the ungaged inflows were minimal during the intervals used for analysis. Most of the hydrograph periods that were selected for analysis included from 3 to 10 days of data. The tracking of a specific streamflow peak down the lower Purgatoire River often was difficult because of large fluctuations in streamflow that occurred due to large diversions for irrigation and various ungaged return flows in a river reach. Traveltimes were not evaluated on a seasonal basis because the time-of-travel of streamflow peaks within a river system is largely dependent on discharge, antecedent streamflow conditions, and the general morphology of the river.

Table 2. Percentage of time daily streamflow occurred at selected tributary streams for the upper and middle reaches of the study area, 1957-67 and 1984-92

[Reach 1 extends from site Q1 to site Q2 (see fig. 1) and includes two gaged tributaries, and reach 2 extends from site Q2 to site Q3 (see fig. 1) and includes five gaged tributaries; >, greater than]

\begin{tabular}{|c|c|c|c|c|}
\hline \multirow[b]{2}{*}{ Season $^{1}$} & \multicolumn{2}{|c|}{$\begin{array}{c}\text { Reach } 1 \\
\text { (January 1957-December 1967) }\end{array}$} & \multicolumn{2}{|c|}{$\begin{array}{c}\text { Reach } 2 \\
\text { (January 1984-December 1992) }\end{array}$} \\
\hline & $\begin{array}{l}\text { Percentage of } \\
\text { time tributary } \\
\text { streamflow } \\
\text { occurred }\end{array}$ & $\begin{array}{l}\text { Percentage of time } \\
\text { tributary streamflow was } \\
\text { less than } 10 \text { percent of } \\
\text { mainstem streamflow }\end{array}$ & $\begin{array}{l}\text { Percentage of } \\
\text { time tributary } \\
\text { streamflow } \\
\text { occurred }\end{array}$ & $\begin{array}{l}\text { Percentage of time } \\
\text { tributary streamflow was } \\
\text { less than } 10 \text { percent of } \\
\text { mainstem streamflow }\end{array}$ \\
\hline Winter & 71 & 91 & 58 & $>99$ \\
\hline Spring & 75 & 63 & 58 & 99 \\
\hline Summer & 78 & 68 & 41 & 93 \\
\hline Fall & 67 & 90 & 38 & $>99$ \\
\hline
\end{tabular}

${ }^{1}$ Winter is December-February, spring is March-May, summer is June-August, fall is September-November. 


\section{Reach 1}

Reach 1 extended $60.6 \mathrm{mi}$ from site Q1 (Purgatoire River below Trinidad Reservoir) to site Q2 (Purgatoire River near Thatcher) (fig. 1). Review of hourly streamflow data for sites Q1 and Q2 did not result in any suitable streamflow events to estimate traveltimes for reach 1 . The reasons for this lack of suitable streamflow largely are due to the substantial effects of diversions to canals and unmeasured return flows in this irrigated study reach. The irrigation canals can return unmeasured quantities of water back to the river a short distance downstream from the diversion structure; parts of these return flows, as well as unmeasured return flows from the irrigated areas, then are diverted by the next downstream irrigation canal. Therefore, a qualitative and quantitative comparison of streamflow hydrographs at sites Q1 and Q2 did not result in an estimate of traveltime for reach 1 .

Because the hourly data could not be used successfully in estimating traveltimes in reach 1, daily mean streamflow data collected between January 1957 and December 1967 were analyzed to see if traveltimes could be estimated from additional streamflow data available at mainstem sites Q1A, Q1B, and Q1C and at tributary sites T1 and T2 (fig. 1). However, the results were similar to those for the hourly data analysis, in that suitable streamflow events at site Q1A could not be distinguished at the two downstream stations (sites Q1B and Q1C). Therefore, traveltime could not be estimated for reach 1 .

\section{Reach 2}

Reach 2 extended $40.1 \mathrm{mi}$ from site Q2 (Purgatoire River near Thatcher) to site Q3 (Purgatoire River at Rock Crossing near Timpas) (fig. 1). Analysis of hourly streamflow records compiled between 1990 and 1994 resulted in selection of 31 suitable streamflow events to estimate traveltime. For reach 2, the relation of traveltime to the instantaneous peak streamflow at site $\mathrm{Q} 2$ is shown in figure $7 \mathrm{~A}$. Traveltime in reach 2 generally increased as the streamflow in the reach decreased, but traveltime also varied for a specific streamflow (fig. 7). Traveltime variation for reach 2 might have occurred because of different antecedent river conditions that existed prior to each streamflow event. The traveltimes computed for reach 2 ranged from about 11 to about 47 hours, with 23 of the 31 instantaneous streamflow peaks within 12 hours of 1 day (fig. 7). A regression analysis indicated that streamflow and traveltime were significantly related $(\mathrm{p}=0.0001)$ in reach 2 , and about 70 percent of the variation that was observed in the traveltimes could be explained by streamflow. Streamflows greater than $100 \mathrm{ft}^{3} / \mathrm{s}$ at sites Q2 and Q3 were infrequent (fig. 6). Most of the traveltime estimates made for reach 2 were computed for instantaneous peak streamflows greater than $100 \mathrm{ft}^{3} / \mathrm{s}$. However, there were five streamflow events selected with instantaneous peak flows less than $100 \mathrm{ft}^{3} / \mathrm{s}$, and their traveltimes through reach 2 ranged from about 23 to about 47 hours (fig. 7).

\section{Reach 3}

Reach 3 extended $58.5 \mathrm{mi}$ from site Q3 (Purgatoire River at Rock Crossing near Timpas) to site Q4 (Purgatoire River near Las Animas) (fig. 1). Analysis of hourly streamflow records compiled between 1990 and 1994 resulted in selection of 30 suitable streamflow events to estimate traveltime. For reach 3 , the relation of traveltime to the instantaneous peak streamflow at site Q3 is shown in figure $7 B$. Traveltime in reach 3 generally increased as streamflow in the reach decreased, but traveltime also varied for a specific streamflow (fig. 7). Traveltime variation for reach 3 might have occurred because of different antecedent river conditions that existed prior to each streamflow event. The traviltimes computed for reach 3 ranged from about 6 to about 61 hours, with 22 of the 30 instantaneous streamflow peaks within 12 hours of 1 day (fig. 7). A regression analysis indicated that streamflow and traveltime were significantly related $(\mathrm{p}=0.0001)$ in reach 3 ; however, only about 40 percent of the variation that was observed in the traveltimes could be explained by streamflow. Streamflows greater than $100 \mathrm{ft}^{3} / \mathrm{s}$ at sites Q3 and Q4 were infrequent (fig. 6). Most of the traveltime estimates made for reach 3 were computed for instantaneous peak streamflows greater than $100 \mathrm{ft}^{3} / \mathrm{s}$. However, there were five streamflow events selected with instantaneous peak flows less than $100 \mathrm{ft}^{3} / \mathrm{s}$, and their traveltimes through reach 3 ranged from about 43 to about 56 hours (fig. 7). 


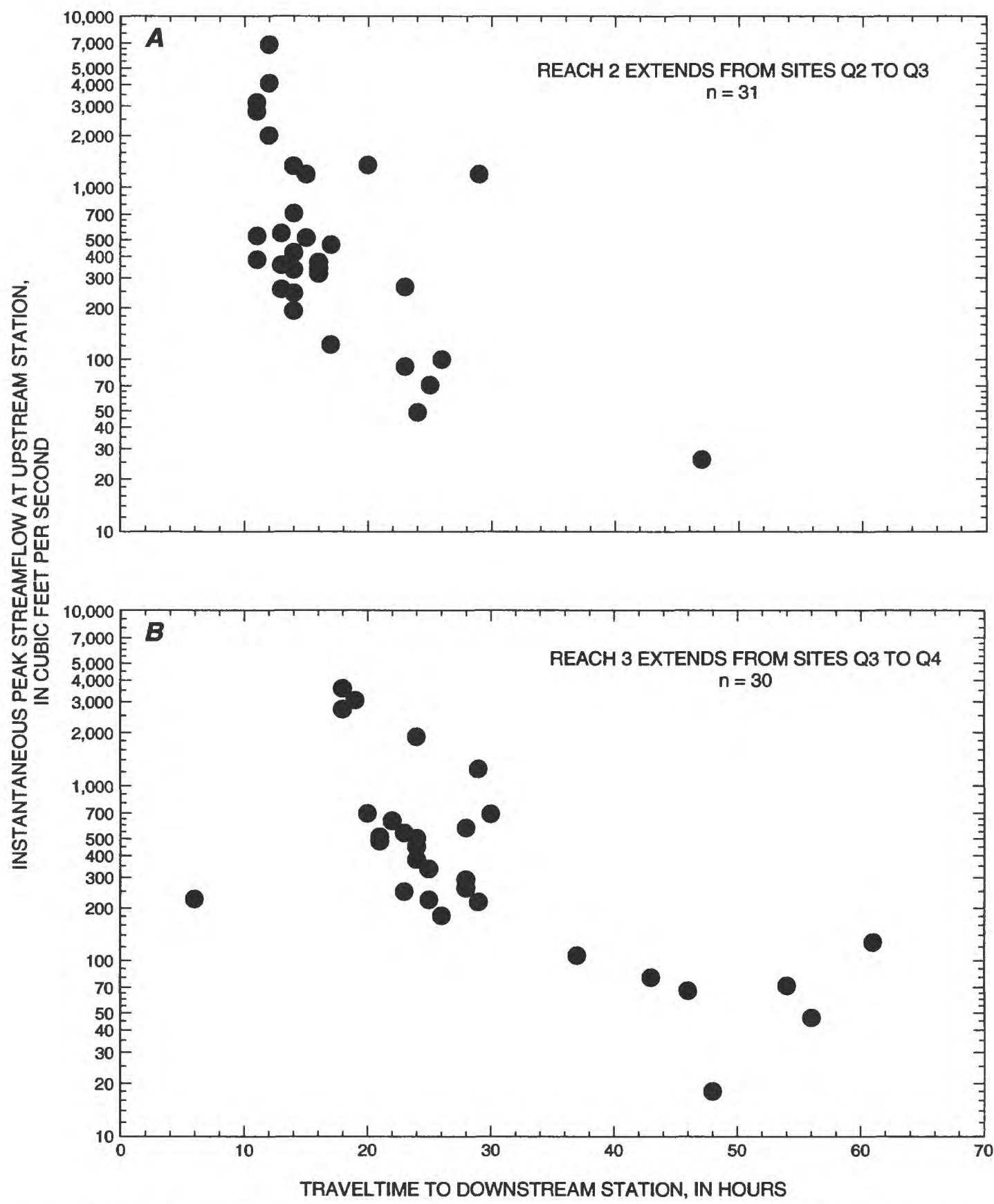

Figure 7. Relation of traveltime to instantaneous peak streamflow for two reaches of the study area, 1990-94.

\section{STREAMFLOW GAINS AND LOSSES}

Determination of streamflow gains and losses requires an accounting of all surface water entering or leaving specified river reaches; ideally, the accounting is done during periods of relatively stable streamflow. For a specified stream reach, conservation of mass can be expressed with the following equation:

$$
\text { Streamflow loss }=\mathrm{RI}+\mathrm{TI}-\mathrm{DO}-\mathrm{RO}+\mathrm{dS}
$$


where:

Streamflow loss $=$ average loss $(+)$ or gain $(-)$ during the estimated period in a river reach, in cubic feet per second;

RI = mainstem streamflow entering a river reach at the upstream site, in cubic feet per second;

$\mathrm{TI}=$ tributary streamflow entering a river reach at all gaged tributaries, in cubic feet per second;

DO = diversion withdrawn out of a river reach by all irrigation canals, in cubic feet per second;

$\mathrm{RO}=$ mainstem streamflow leaving a river reach at the downstream site, in cubic feet per second; and

$\mathrm{dS}=$ change in storage within the river reach during the estimated period, in cubic feet per second.

Streamflow losses (positive values) can result from evaporation from the river and saturated soil surfaces, from transpiration by phreatophytes in adjacent flood-plain areas, and by an outflow to ground water. Streamflow gains (negative values) can result from an inflow of ground water and from ungaged streamflows contributed to the river.

Daily records of diversion outflow (DO), mainstem reach inflow (RI), and mainstem reach outflow (RO) were used for 1957-67 and 1984-92. Daily tributary inflow (TI) records were used for two tributaries [sites T1 and T2 (fig. 1)] in reach 1 (1957-67) and for five tributaries [sites T3 to T7 (fig. 1)] in reach 2 (1984-92). No records of tributary inflow were available for reach 3 .

Change in storage $(\mathrm{dS})$ within a river reach during the specified period was assumed to be negligible. To minimize the error introduced by this assumption, the accounting period was adjusted (upstream traveltime adjustment) so that the same streamflow peaks were included in the average streamflow into (RI) and out of (RO) the reach. Streamflow loss was calculated for daily periods and for streamflow-event periods. For daily streamflowloss estimates, the flow hydrograph from the upstream site was visually compared to the flow hydrograph from the downstream site to select an appropriate traveltime by which to adjust each period for the upstream site. The leading edge, streamflow peak, and the trailing edge for each pair of distinguishable streamflow events were compared (fig. $8 A$ ). A single constant traveltime adjustment (fig. $8 B$ ) was used to estimate traveltime-adjusted streamflow into each river reach for 1957-67 (reach 1) and 1984-92 (reach 2 and reach 3 ).

Streamflow loss also was calculated for selected streamflow-event periods. Streamflow events having similar characteristics (leading edge, streamflow peak, and trailing edge) at upstream and downstream sites (first and second periods in fig. 9) were selected. Streamflow events lacking these similarities (third period in fig. 9) were not. Streamflow loss or gain was computed for each period using the cumulated mainstem inflow (RI) at the upstream site (area under the curve from U1 to U2 in fig. 9), the cumulated mainstem outflow (RO) at the downstream site (area under the curve from D1 to D2 in fig. 9), the total inflow at gaged tributaries (TI), and the total irrigation diversion outflow (DO). Thus, when total inflow exceeded total outflow, water was lost in the river reach and, when total outflow exceeded total inflow, water was gained in the river reach.

\section{Reach 1}

Tracking of specific streamflow peaks was not possible through reach 1 ; therefore, available streamflow data in reach 1 were inadequate for determining reasonable estimates of traveltime. Visual inspection of many daily streamflow hydrographs for sites Q1, Q1A, Q1B, Q1C, and $\mathrm{Q} 2$ also indicated that large and almost continuous inflows of ungaged water (either field tailwater, canal wastewater, return flows, or ungaged tributary inflows) entered into reach 1 on a regular basis throughout the irrigation season. Lacking reasonable estimates of traveltime and the ungaged side-channel inflows into reach 1 prevented accurate determination of streamflow gains and losses.

\section{Reach 2}

Analyses of daily mean streamflow gains and losses for reach 2 were made for more than 2,900 days between 1984 and 1992. A constant 1-day advance (traveltime adjustment) of the upstream flow, which 


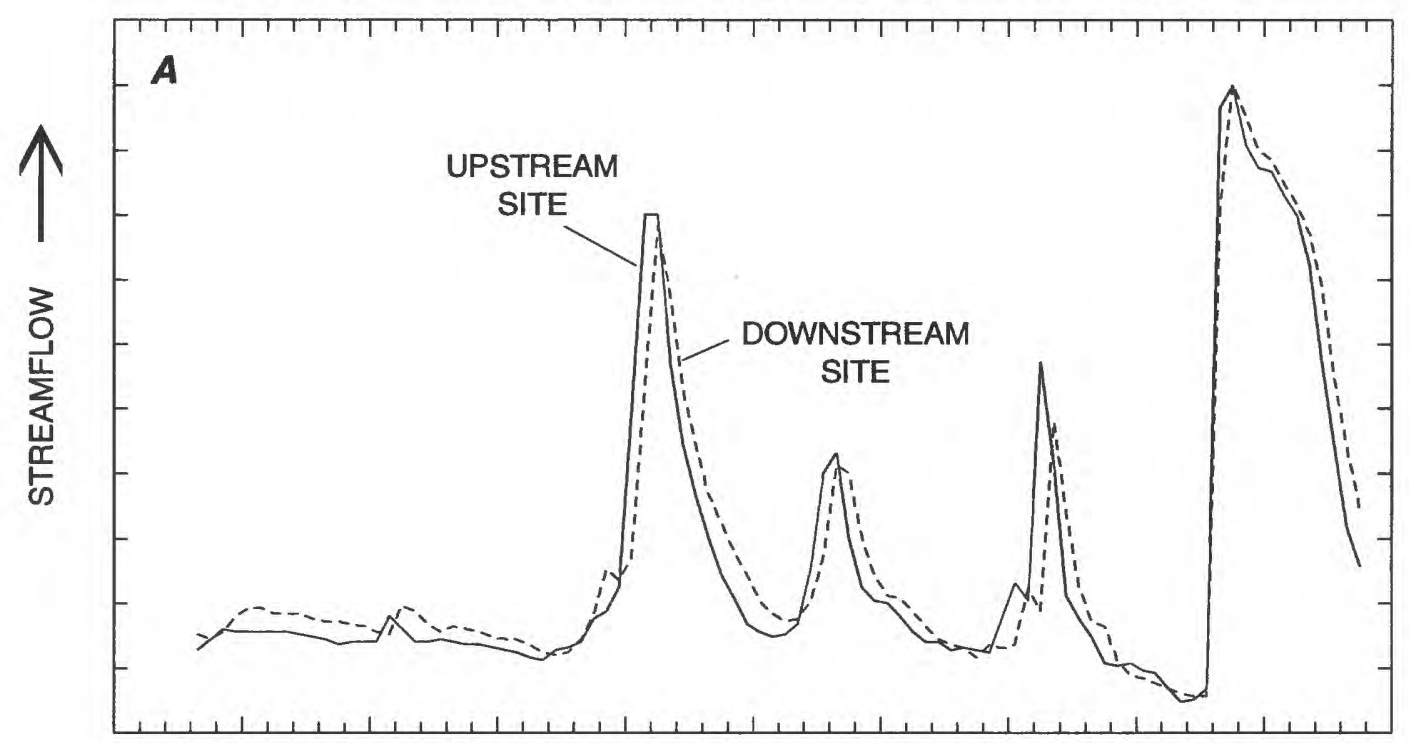

UPSTREAM HYDROGRAPH ADVANCED 1 DAY FOR REACH TRAVELTIME

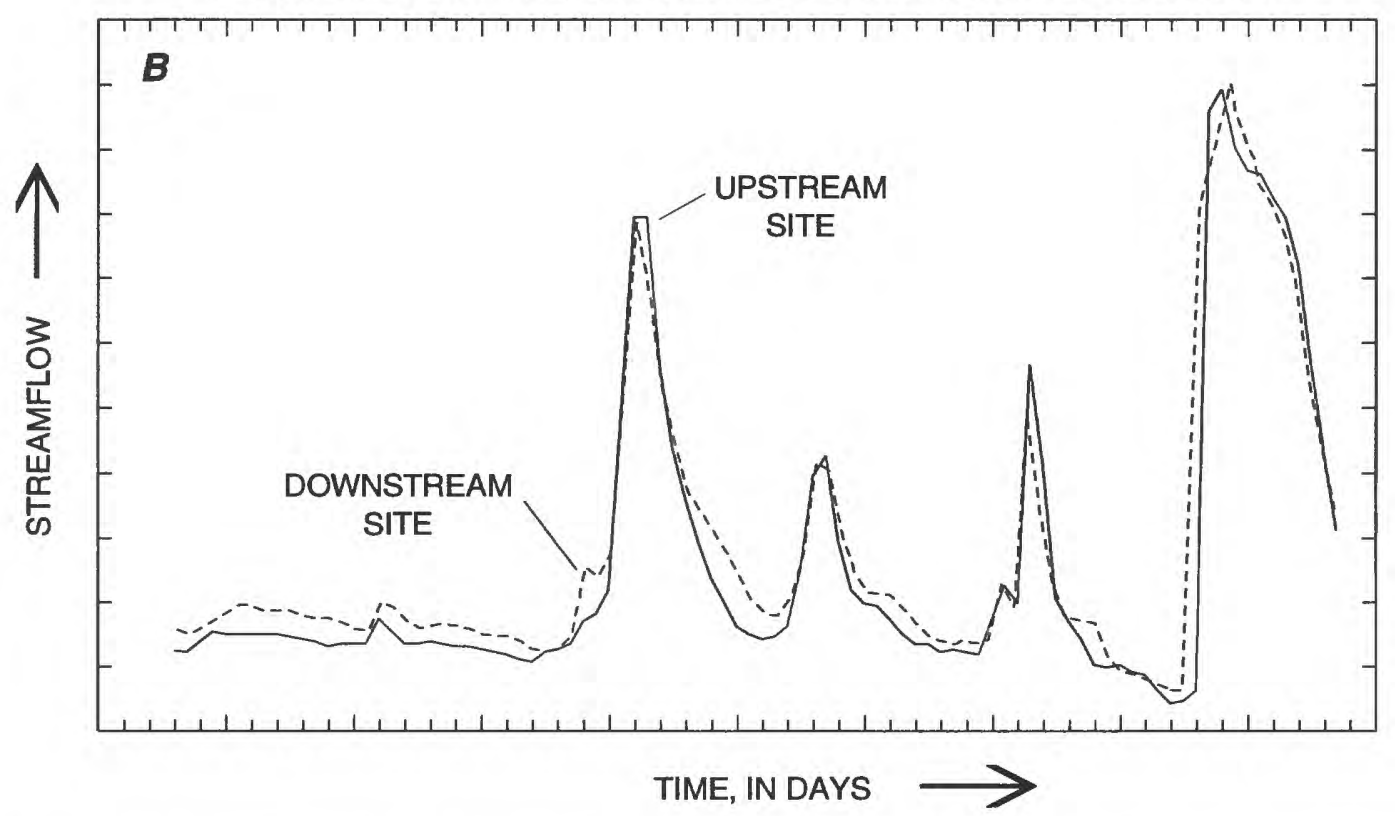

Figure 8. Example of $(A)$ unadjusted hydrographs and $(B)$ a traveltime-adjusted upstream hydrograph of daily mean streamflow.

was based on a significant correlation between upstream and downstream streamflow of 0.92 $(\mathrm{p}=0.0001$ ), was used in reach 2 for the computation of daily streamflow gains and losses. Visual inspection of many streamflow hydrographs for sites Q2 and Q3 also indicated that a 1-day advance of the upstream hydrograph was an appropriate traveltime adjustment when using daily streamflow data. The boxplots of these calculated streamflow gains and losses are shown in figure 10; a negative value indicated a streamflow gain and a positive value indicated a streamflow loss. Median values of streamflow gains and losses in reach 2 were close to zero during every season (fig. 10). 


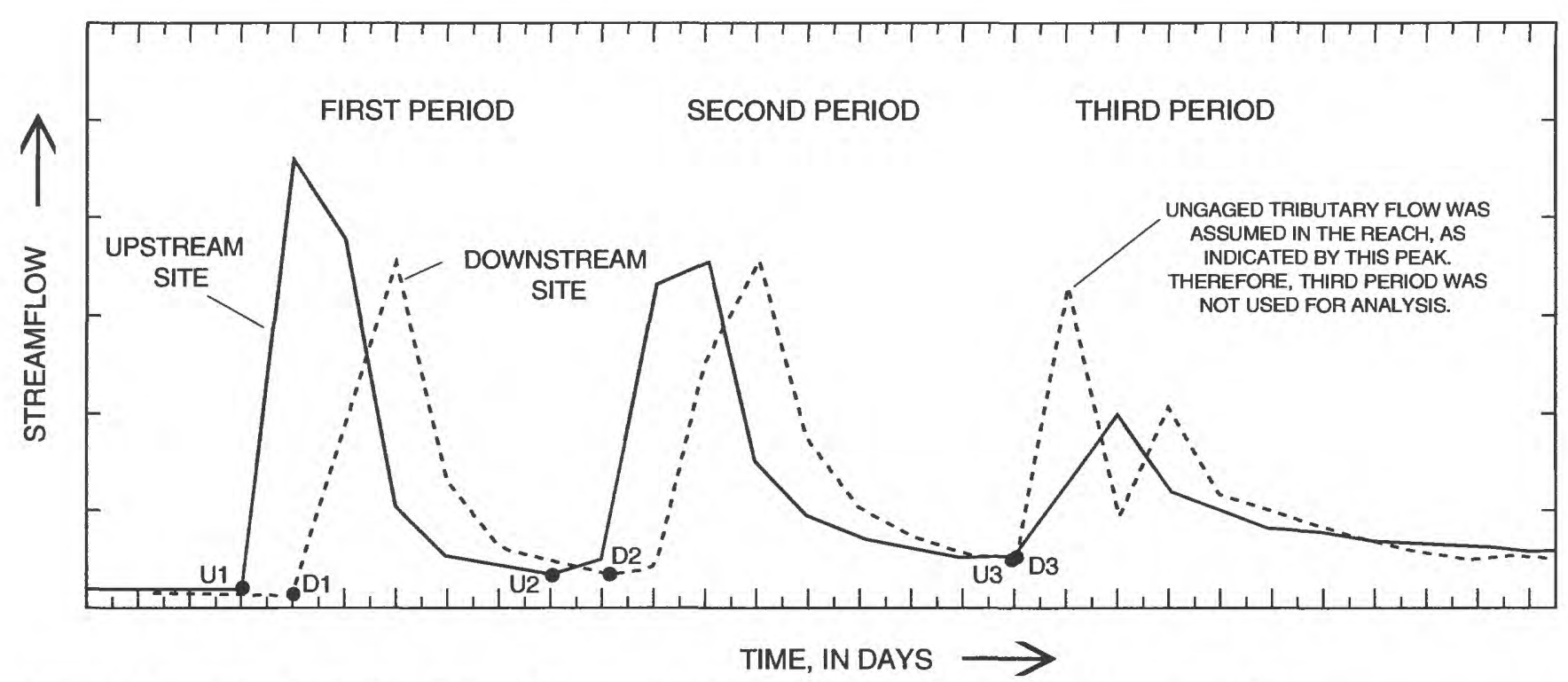

Figure 9. Example of selection of streamflow-event periods for analysis of daily streamflow gain and loss.

The statistical summary of daily estimates for reach 2 (table 3 ) indicated that streamflow gains and losses between -4.9 and $6.0 \mathrm{ft}^{3} / \mathrm{s}$ were common during all four seasons. Although large daily gains and losses were computed (table 3 ), generally most of the values were less than \pm 20 percent of the daily mean streamflow. During winter, gain-and-loss computations were made for 718 days, resulting in a daily median loss of zero; during spring, gain-and-loss computations made for 736 days had a daily median gain of $2 \mathrm{ft}^{3} / \mathrm{s}$; during summer, gain-and-loss computations made for 752 days had a daily median loss of $1 \mathrm{ft}^{3} / \mathrm{s}$; and during fall, gain-and-loss computations made for 753 days had a daily median loss of $1 \mathrm{ft}^{3} / \mathrm{s}$ (table 3 ). Statistical analysis, using a two-tailed t-test (Iman and Conover, 1983), was used to assess whether daily streamflow gains and losses were significantly different from zero during some seasons. A two-tailed hypothesis test assumes that the difference can be greater than or less than zero. Results of the test using the 1984-92 estimated streamflow gain-and-loss data indicated that only during the fall were daily gains or losses in reach 2 significantly different from zero at the 95-percent confidence level.

In addition to the more than 2,900 daily computations of streamflow gains and losses in reach 2 , boxplots are shown in figure 10 that summarize streamflow gain-and-loss calculations for more than 100 selected streamflow events between 1984 and 1992. Gain-and-loss computations for
8 winter streamflow events that were analyzed had a daily median gain of $1 \mathrm{ft}^{3} / \mathrm{s}$; for 26 spring streamflow events, a daily median gain of $1.5 \mathrm{ft}^{3} / \mathrm{s}$; for 48 summer streamflow events, a daily median loss of $3.0 \mathrm{ft}^{3} / \mathrm{s}$; and for 24 fall streamflow events, a daily median loss of $1.5 \mathrm{ft}^{3} / \mathrm{s}$ (table 3 ). The streamflow-event estimates in reach 2 ranged from a daily gain of $30 \mathrm{ft}^{3} / \mathrm{s}$ to a daily loss of $58 \mathrm{ft}^{3} / \mathrm{s}$ (table 3 ).

\section{Reach 3}

Analysis of daily mean streamflow gains and losses for reach 3 was made for more than 3,200 days between 1984 and 1992. A constant 1-day advance (traveltime adjustment) of the upstream flow, which was based on a significant correlation between upstream and downstream streamflow of 0.74 $(p=0.0001)$, was used in reach 3 for the computation of daily streamflow gains and losses. Visual inspection of many daily streamflow hydrographs for sites Q3 and Q4 also indicated that a 1-day advance of the upstream hydrograph was an appropriate traveltime adjustment when using daily streamflow data. The boxplots of these calculated streamflow gains and losses are shown in figure 11; a negative value indicated a streamflow gain and a positive value indicated a streamflow loss. Median values of streamflow gains and losses in reach 3 indicated a daily streamflow gain during every season (fig. 11). 


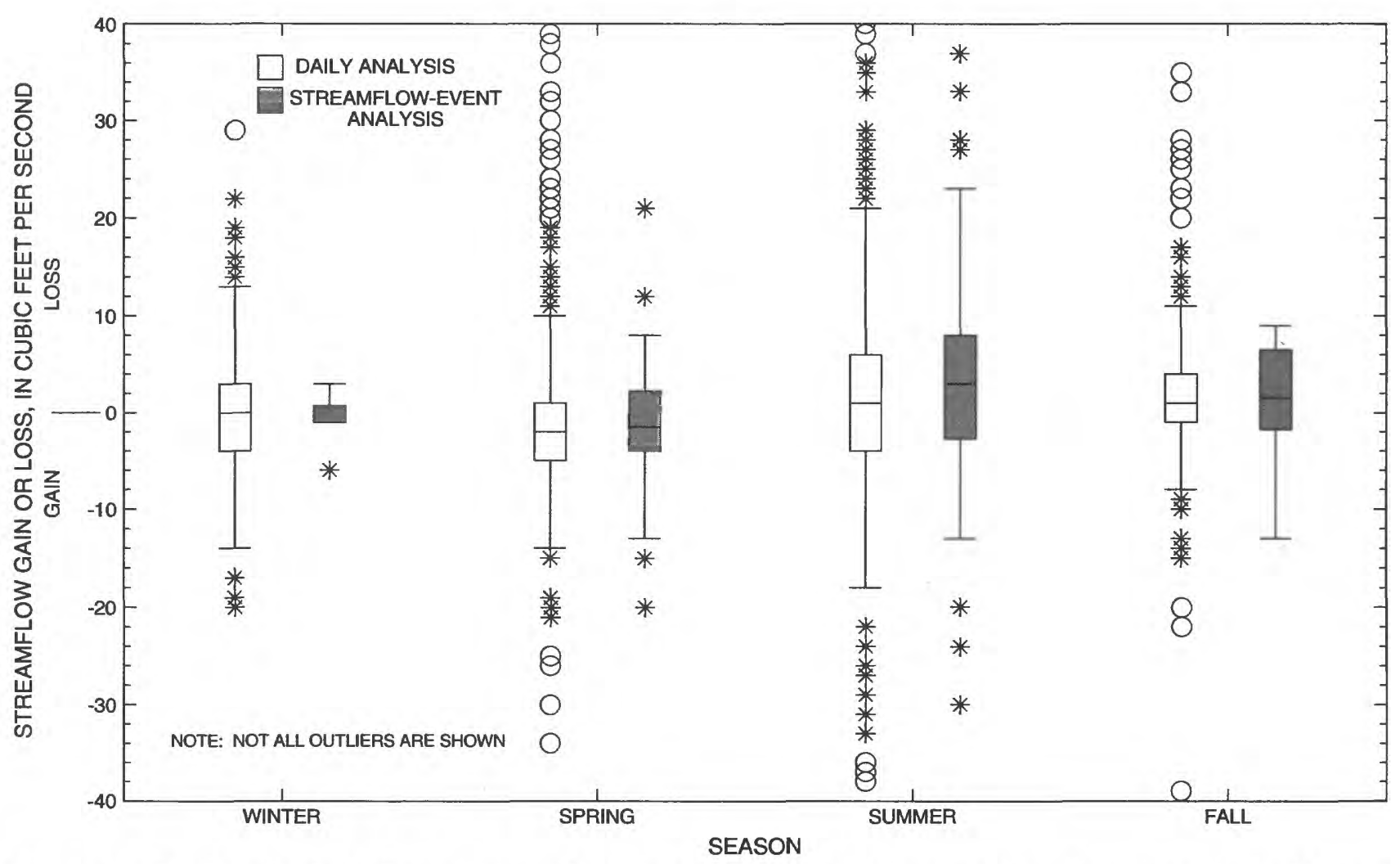

Figure 10. Boxplots showing daily mean streamflow gains and losses and daily mean streamflow-event gains and losses for reach 2 of the study area, 1984-92.

The statistical summary of daily estimates for reach 3 (table 3 ) indicated that median streamflow gain was at least $2 \mathrm{ft}^{3} / \mathrm{s}$ during all four seasons. During winter, gain-and-loss computations were made for 812 days, resulting in a daily median gain of $2 \mathrm{ft}^{3} / \mathrm{s}$; during spring, gain-and-loss computations made for 828 days had a daily median gain of $8.7 \mathrm{ft}^{3} / \mathrm{s}$; during summer, gain-and-loss computations made for 828 days had a daily median gain of $16 \mathrm{ft}^{3} / \mathrm{s}$; and during fall, gain-and-loss computations made for 819 days had a daily median gain of $12 \mathrm{ft}^{3} / \mathrm{s}$ (table 3 ). Statistical analysis, using a one-tailed t-test (Iman and Conover, 1983), was used to assess if daily streamflow gains were significantly greater than zero during some seasons. A one-tailed hypothesis test assumes that the difference is greater than zero. Results of the test using the 1984-92 estimated gain-and-loss data indicated that during all four seasons, the daily gains of streamflow in reach 3 were significantly different from zero at the 95-percent confidence level.

In addition to the more than 3,200 daily computations of streamflow gains and losses in reach 3 , boxplots are shown in figure 11 that summarize streamflow gain-and-loss calculations for 88 selected streamflow events between 1984 and 1992. Gain-and-loss computations for 3 winter streamflow events that were analyzed had a daily median gain of $2 \mathrm{ft}^{3} / \mathrm{s}$; for 19 spring streamflow events, a daily median gain of $7 \mathrm{ft}^{3} / \mathrm{s}$; for 57 summer streamflow events, a daily median gain of $15 \mathrm{ft}^{3} / \mathrm{s}$; and for 9 fall streamflow events, a daily median gain of $4 \mathrm{ft}^{3} / \mathrm{s}$ (table 3). The streamflow-event estimates in reach 3 ranged from a daily gain of $275 \mathrm{ft}^{3} / \mathrm{s}$ to a daily loss of $224 \mathrm{ft}^{3} / \mathrm{s}$ (table 3 ).

The daily occurrence of streamflow gains in reach 3 could be because of ground-water inflows and other ungaged streamflows that might occur in an irrigated river reach; the sources likely are from field tailwater, canal operations, and other ungaged surfacewater sources. No records of tributary inflow were available for reach 3 . Ungaged tributary inflow into reach 3 was assumed to be small. During those days when side-channel inflows from ungaged tributary streams were large, gain-and-loss computations indicated a large daily gain; these large reported streamflow gains were outlier values in the gain-andloss boxplots (fig. 11). 


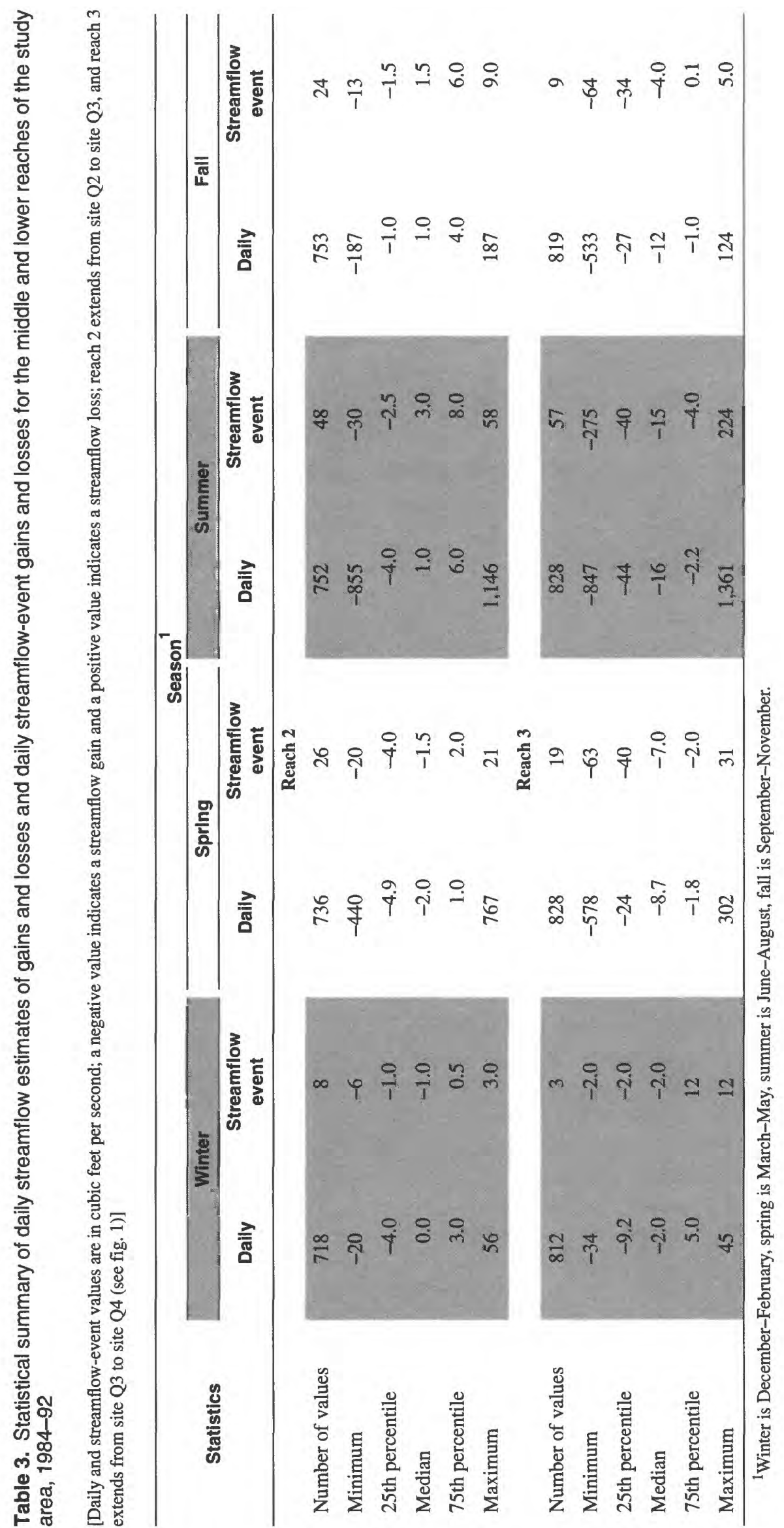




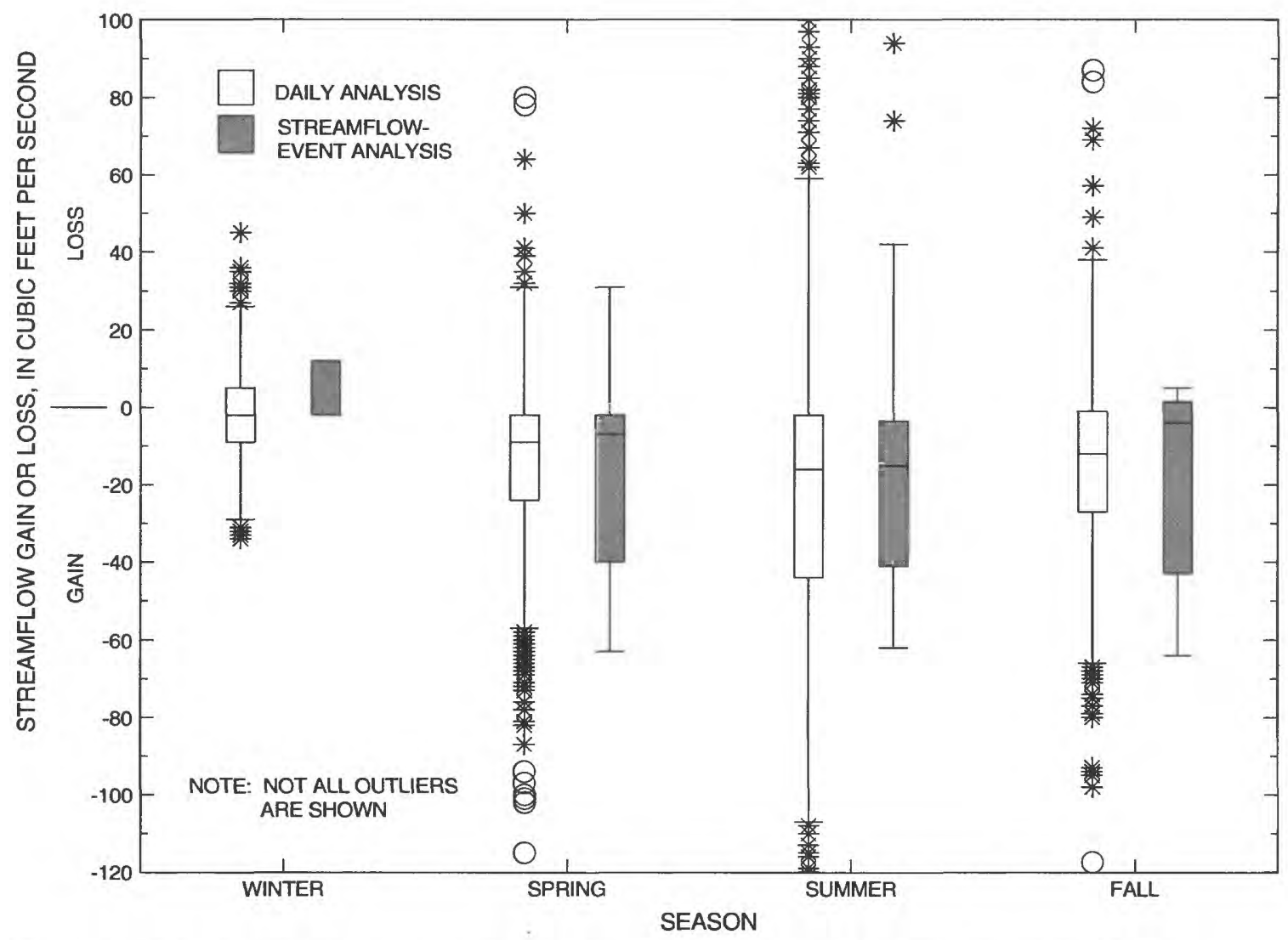

Figure 11. Boxplots showing daily mean streamflow gains and losses and daily mean streamflow-event gains and losses for reach 3 of the study area, 1984-92.

\section{CONFIDENCE IN ACCURACY OF ESTIMATES}

Overall confidence in the estimation of streamflow traveltimes and of streamflow gains and losses using historical streamflow and diversion records was considered to be good to fair for reaches 2 and 3 , which compose about $100 \mathrm{mi}$ of the lower Purgatoire River. Because available information was insufficient to quantify the return flows and other tributary contributions (ungaged inflows) in reach 3 , the magnitude of errors in assuming that ungaged streamflow in an irrigated river reach generally was inconsequential could not be evaluated directly. The streamflow-event analyses that were made for reaches 2 and 3 did help to strengthen the confidence in the accuracy of the reported estimates of streamflow gains and losses for these two reaches.

The hydrologic data available for reach $1 \mathrm{did}$ not provide adequate information to estimate streamflow traveltime and to determine streamflow gains and losses accurately. Additional information that could improve confidence in traveltime estimates and quantify streamflow gains and losses for specific flow conditions better include:

1. Dye-tracer studies conducted during two or more flows, preferably a low flow and a high flow, to determine traveltimes for the transport of streamflows to downstream river locations.

2. Identification and quantification of ungaged inflows to the lower Purgatoire River system, including the extent of operational practices by canals (sluicing); the surface routing of irrigation field tailwater, waste flows, and other sources of return flows; and the magnitude of streamflow contributions by tributary streams.

Determination of streamflow traveltime and better estimates of streamflow gains and losses in a complex irrigated surface-water and groundwater system, such as in the lower Purgatoire River, could be approximated by the use of computer 
models. A numerical flow model could be developed to provide a reliable means of determining traveltimes and transit losses for this river, but accurate estimates require accurate data to be available for each river reach.

\section{SUMMARY}

The lower Purgatoire River flows more than 160 miles from Trinidad Dam and Reservoir to its confluence with the Arkansas River near Las Animas, Colorado. Water supplies in the area are overappropriated and, at times, shortages of irrigation water occur when the demand by canal systems exceeds the available streamflow. A better knowledge of streamflow traveltime and streamflow gains and losses along the lower Purgatoire River would enable more informed management decisions about the availability of water supplies for irrigation use in southeastern Colorado. In 1994-95, the U.S. Geological Survey, in cooperation with the Purgatoire River Water Conservancy District and the Arkansas River Compact Administration, began an evaluation of streamflow traveltime and streamflow gains and losses using historical records for 15 surface-water sites and daily diversion data for 13 canals in the study area. The irrigation canals divert streamflow from the Purgatoire River usually from April through the middle of November; peak diversions generally are largest from June through August. Eleven canals diverted water in reach 1 (60.6 miles), there were no surface-water diversions in reach 2 (40.1 miles), and two canals diverted water in reach 3 (58.5 miles). At times, there was little surfacewater flow in some river reaches because the irrigation canals diverted all the river water.

Two streamflow-gaging stations in reach 1 were used to evaluate streamflow entering the study area during two relatively long-term periods of time before and after the commencement of operations at Trinidad Dam in 1979. Seasonal comparisons of daily streamflow during two time periods (1957-67 and 1984-92) indicated that regulation of the Purgatoire River at Trinidad Reservoir had affected the seasonal quantity and timing of streamflow into the study area. Daily median streamflow during 1984-92 (site Q1) was larger than during 1957-67 (site Q1A) during the summer, but was generally smaller during the other three seasons.
The availability and completeness of streamflow data for tributary streams in the study area varied seasonally and spatially in the three river reaches. Analysis of daily mean streamflow data for two gaged tributaries in reach 1 and for five gaged tributaries in reach 2 indicated that tributary streams contributed streamflow during many days of the year; however, tributary streamflow that exceeded 10 percent of mainstem streamflow occurred infrequently. Most of the time, the total gaged tributary streamflow in reaches 1 and 2 contributed less than 10 percent of the mainstem streamflow, indicating that tributary streams generally were not a source of substantial streamflow (inflow) to the lower Purgatoire River. No tributary streamflow data were available for reach 3.

Traveltime analyses were used to determine when streamflows would arrive at three downstream sites. The frequent diversion of streamflow for irrigation purposes and substantial ungaged streamflow in the most upstream reach prevented the tracking of streamflow through reach 1 . Therefore, an estimation of streamflow traveltime for the 60.6 miles of river in reach 1 could not be made using the available data. Hourly streamflow data from 1990 through 1994 were used to estimate traveltimes for 31 (reach 2) and 30 (reach 3) suitable streamflow events for about 100 miles of the lower Purgatoire River. In reach 2, the traveltime of streamflow for the 40.1 miles ranged from about 11 to about 47 hours and in reach 3, traveltime for the 58.5 miles ranged from about 6 to about 61 hours. The traveltime in the river reaches generally increased as the streamflow decreased, but also varied for a specific streamflow in both reaches.

Streamflow gains and losses were estimated using daily-streamflow data at the upstream and downstream sites, available tributary data, and daily diversion data. The difference between surface-water inflows and surface-water outflows in a river reach determined the quantity of water gained or lost. In reach 1 , difficulties in establishing streamflow traveltime prevented the determination of streamflow gains or losses. From 1984 through 1992, more than 2,900 daily estimates of streamflow gains or losses were made for reach 2 and more than 3,200 estimates were made for reach 3 that indicated daily gains and losses in streamflow were common during all seasons of the year. Although some large daily streamflow gains and losses were computed, most daily estimates indicated small gains and losses in streamflow. Daily median values of streamflow gains and losses for 
reach 2 were close to zero during every season, whereas median values for reach 3 indicated a daily streamflow gain of at least $2 \mathrm{ft}^{3} / \mathrm{s}$ during all seasons.

In reaches 2 and 3 , streamflow gains and losses were computed for selected streamflow-event periods from 1984 through 1992. Time periods were selected for streamflow-event analysis of streamflow gains and losses by visually matching inflow and outflow hydrograph periods for distinctive streamflow events. In reach 2, more than 100 streamflow-event calculations were made, and daily median values were close to zero during every season. In reach 3 , 88 streamflow-event calculations were made and daily median values indicated a daily gain of at least $2 \mathrm{ft}^{3} / \mathrm{s}$ in streamflow during all four seasons.

\section{REFERENCES CITED}

Abbott, P.O., 1985, Description of water-systems operations in the Arkansas River Basin, Colorado: U.S. Geological Survey Water-Resources Investigations Report 85-4092, 67 p.

Bureau of Reclamation, 1964a, Irrigation report on the Trinidad Project, Colorado-v. 1, Irrigation report: U.S. Department of the Interior, Report 61, 76 p. (Revised September 1964.)

-1964b, Irrigation report on the Trinidad Project, Colorado-v. 2, Appendix A, supplement-water supply and utilization: U.S. Department of the Interior, Report 61, 95 p. (Revised April 1964.) 1988, Trinidad Project, Colorado, Review of operating principles, final report: Loveland, Colo., U.S. Department of the Interior, $59 \mathrm{p}$.

Colorado Cooperative Crop and Livestock Reporting Service, comp., 1995, Colorado agricultural statistics, 1995: Denver, Colorado Department of Agriculture, $222 \mathrm{p}$.
Colorado Department of Natural Resources, 1975, Purgatoire River traveltime and transit losses study: Denver, Office of the State Engineer, Division of Water Resources, v. 1, paging unknown.

Helsel, D.R., and Hirsch, R.M., 1992, Statistical methods in water resources: New York, Elsevier, Studies in Environmental Science 49, 522 p.

Iman, R.L., and Conover, W.J., 1983, A modern approach to statistics: New York, Wiley, 497 p.

Lindauer, I.E., and Ward, R.T., 1968, A survey of the woody phreatophytes in the lower Arkansas River Valley of Colorado: Fort Collins, Colorado State University, $47 \mathrm{p}$.

Qazi, A.R., and Krason, Jan, 1976, A study of the transit losses in the Purgatoire River, southeastern Colorado: Denver, Office of the State Engineer, Division of Water Resources, $30 \mathrm{p}$.

Rantz, S.E., and others, 1982, Measurement and computation of streamflow- $v$. 1, Measurement of stage and discharge, v. 2, Computation of discharge:

U.S. Geological Survey Water-Supply Paper 2175, v. 1 , p. 1-284; v. 2, p. 285-631.

U.S. Department of Agriculture, 1988, Colorado irrigation guide: Denver, Soil Conservation Service [known since 1995 as the Natural Resource Conservation Service], [variously paged]. (Revised.)

von Guerard, Paul, Abbott, P.O., and Nickless, R.C., 1987, Hydrology of the U.S. Army Pinon Canyon Maneuver Site, Las Animas County, Colorado: U.S. Geological Survey Water-Resources Investigations Report 87-4227, 117 p.

von Guerard, Paul, Parker, R.S., and Dash, R.G., 1993, Assessment of effects of military maneuvers on the streamflow, water quality, and sediment yields at the U.S. Army Pinon Canyon Maneuver Site, Las Animas County, Colorado: U.S. Geological Survey WaterResources Investigations Report 91-4095, 84 p. 